Fall 2006

\title{
How Antidiscrimination Law Learned to Live with Racial Inequality
}

Matthew Lindsay

University of Baltimore School of Law, mlindsay1@ubalt.edu

Follow this and additional works at: http://scholarworks.law.ubalt.edu/all_fac

Part of the Civil Rights and Discrimination Commons, and the Supreme Court of the United States Commons

\section{Recommended Citation}

How Antidiscrimination Law Learned to Live with Racial Inequality, 75 U. Cin. L. Rev. 87 (2006)

This Article is brought to you for free and open access by the Faculty Scholarship at ScholarWorks@University of Baltimore School of Law. It has been accepted for inclusion in All Faculty Scholarship by an authorized administrator of ScholarWorks@University of Baltimore School of Law. For more information, please contact snolan@ubalt.edu. 


\section{HOW ANTIDISCRIMINATION LAW \\ LEARNED TO LIVE WITH RACIAL INEQUALITY}

Matthew J. Lindsay*

I: Racial Proportionality in the Civil Rights Era

A. Federal Enforcement of the Antidiscrimination Mandate, 1965-1971

1. Racial Underrepresentation as "Sociological Radar"

2. Racial Proportionality as an End in Itself: The Philadelphia Plan

B. Racial Proportionality in the Lower Federal Courts ........... 100

C. Disparate Impact and the Supreme Court .......................... 104

D. Racial Proportionality and Equal Protection: The Case of Construction Set-Asides

II. Colorblind Equality and the Production of Racial Difference....... 108

A. Racial Inequality in a "Nation of Minorities": The Ethnicity Critique of Racial Proportionality

B. Equality as Colorblind Competition

1. Market Outcomes as a Register of Racial

Difference

2. "Social Engineering"

III. Colorblind Competition, Racial Difference, and the

Retrenchment of Antidiscrimination Law.

A. Title VII: Disparate Impact and the Emergence of the Market Rationality Standard

B. Ethnic Difference and Equal Protection: Public Contracting

C. The Ambiguous Legacy of Racial Proportionality:

Affirmative Action in Higher Education.

IV. Conclusion

* Associate, Foley Hoag LLP, Boston. M.A. History, University of Chicago, 1995; J.D., Yale Law School, 2002; Ph.D. History, University of Chicago (expected 2007). For their valuable insights, 1 am grateful to Owen Fiss, David Fontana, Robert Gordon, Robert Post, Dan Sharfstein, Reva Siegel, and especially to Kim Reilly. Portions of this Article have been completed with the generous support of the American Academy of Arts and Sciences. 
This Article explores a great paradox at the heart of the prevailing paradigm of American antidiscrimination law: the colorblindness ideal. In theory, and often in practice, that ideal is animated by a genuine commitment to liberal, individualist, race-neutral egalitarianism. For many of its partisans, colorblindness entails not only a negative injunction against race-conscious decisionmaking, but also, crucially, an affirmative program for the achievement of true racial equality. For these proponents, scrupulously race-neutral decisionmaking both advances the interests of racial minorities and embodies the best aspirations of the civil rights movement. In this worldview, colorblindness offers the only true antidote for both racial inequality and racism itself, hastening the day when race will be, as the Supreme Court has put it, "truly irrelevant." And indeed, the logical simplicity and moral clarity of the colorblindness ideal give it a certain intuitive appeal. $^{2}$

This Article argues that recent history in fact belies such claims. Critics of the colorblindness model have long observed that the Supreme Court's insistence on race-neutrality has proven a poor remedy for entrenched racial inequality. ${ }^{3}$ Remarkably - and here is the paradoxthe Court's very enforcement of the colorblindness ideal has itself fueled the reproduction of racial difference. In the service of colorblindness, the Burger and Rehnquist Courts, in dialogue with a host of influential social scientists and public intellectuals, redefined racial inequality from a wrong in and of itself - and as such a presumptive object of civil rights enforcement - to a morally benign legal irrelevancy. The Court did so by reconstructing African Americans from a class characterized, for the purposes of civil rights enforcement, by the systematic social, economic,

1. Adarand Constructors, Inc. v. Pena, 515 U.S. 200, 229 (1995).

2. In order to focus on the colorblindness ideal's paradoxical internal logic, this Article brackets the important question of whether the rhetoric of race-neutrality sometimes is invoked as a convenient subterfuge for old-fashioned white supremacist racial projects. See, e.g., Randall Kennedy, Persuasion and Distrust: A Comment on the Affirmative Action Debate, 99 HARV. L. REV. 1327, 1344 (1986) (documenting the Reagan administration's "underlying impulse to protect the prerogatives of whites against the least hint of encroachment by claims of racial justice," all in the name of colorblindness).

3. As courts and scholars have noted, a legal equality regime that enjoins only racial classifications often has the effect of permitting, and even ratifying, a host of facially "race-neutral" policies and practices that perpetuate pre-existing forms of racial inequality. Prominent examples include the use of educational and testing requirements as a condition of employment eligibility (see, e.g., Griggs v. Duke Power Co. 401 U.S. 424 (1971)); the practice of funding public schools through local property taxes (see, e.g., San Antonio Indep. Sch. Dist. v. Rodriguez, 411 U.S. 1 (1973)); the recognition of workplace seniority accrued in an era of overt racial discrimination (see, e.g., Quarles v. Phillip Morris Co., 279 F.Supp. 505 (E.D.Va. 1968)). See generally Alan David Freeman, Legitimizing Racial Discrimination Through Antidiscrimination Law: A Critical Review of Supreme Court Doctrine, 62 MINN. L. REV. 1049 (1978); Reva B. Siegel, Discrimination in the Eyes of the Law: How 'Color Blindness' Discourse Disrupts and Rationalizes Social Stratification, 88 CAL. L. REV. 77 (2000). 
and political subordination endured by its members, to a class characterized by its ethnically distinctive culture. By unveiling this critically neglected racial project, this Article casts new light on how American antidiscrimination law, though unequivocally committed to racial equality in theory, has learned to live with racial inequality in fact. $^{4}$

As it has been articulated by its most vocal champions, the colorblindness ideal is, at least in theory, genuinely egalitarian. By disavowing classifications drawn on the basis of race, the theory runs, we affirm the moral irrelevance of race and honor equal opportunity. As a theory of equality, the colorblindness ideal appeals for its moral and political authority to a vision of free competition among individuals in a race-neutral marketplace, where scarce social and economic goods are distributed approximately according to individual merit. ${ }^{5}$ Notwithstanding its success in the legal marketplace of ideas, however, colorblindness has always presented its friends and foes alike with a nagging contradiction: If race is truly irrelevant, why have blacks and other minority groups continued to occupy, in vastly disproportionate numbers, the lowest rungs of the occupational and educational ladder, long after Brown v. Board of Education ${ }^{6}$ and the Civil Rights Act of $1964^{7}$ presumably removed, or at least minimized, racial barriers to individual achievement? This tension has only grown sharper and more urgent with the passage of time, as new generations of blacks have come of age in the post-Jim Crow era, presumably enjoying the benefits of equal education and fair employment. ${ }^{8}$ How has the colorblindness

4. The doctrinal "retrenchment" of civil rights enforcement under the Burger and Rehnquist Courts has, since its inception in the early 1970 s, provoked vigorous objections from dissenting judges and legal scholars alike. Two constitutional law developments in particular-the adoption of a strict discriminatory intent requirement (see Washington v. Davis, 426 U.S. 229 (1976); Arlington Heights v. Metro. Hous. Dev. Corp., 429 U.S. 252 (1977); Pers. Adm'r of Mass. v. Feeney, 442 U.S. 256 (1979)) and the establishment of racial classifications as the exclusive trigger for strict judicial scrutiny (see Regents of Univ. of Cal. v. Bakke, 438 U.S. 265 (1978); Adarand, 515 U.S. at 200) have long drawn particularly trenchant criticism. See, e.g., Owen M. Fiss, Groups and the Equal Protection Clause, 5 PHIL. \& PUBL. AFF. 107 (1976); Freeman, supra note 3; Kenneth L. Karst, Equal Citizenship Under the Fourteenth Amendment, 91 HARV. L. REV. 1 (1977); Charles R. Lawrence III, The Id, the Ego, and Equal Protection: Reckoning with Unconscious Racism, 39 STAN. L. REV. 317 (1987); Daniel R. Ortiz, The Myth of Intent in Equal Protection, 41 STAN. L. REV. 1105 (1989); David A. Strauss, Discriminatory Intent and the Taming of Brown, 56 U. CHI. L.R. 935 (1989).

5. Important analyses of colorblindness discourse and its relationship to market-oriented notions of equality include MiCHAEL OMI \& HOWARD WINANT, RACIAL FORMATION IN THE UNITED STATES FROM THE 1960s TO THE 1990s (2nd ed. 1994); Neil Gotanda, $A$ Critique of "Our Constitution is ColorBlind," 44 STAN. L. REV. 1 (1991); Siegel, Discrimination, supra note 3.

6. 347 U.S. 483 (1954).

7. Pub. L. No. 88-352, 78 Stat. 241 (1964) (codified in 42 U.S.C. $\S 2000$ e (2000)).

8. As Morton Horwitz has pointedly put it, adherents to a liberal individualist conception of civil rights enforcement have long been "unable to explain why an unusually large number of members 
ideal, in all of its liberal triumphalism, remained intellectually, politically, and morally viable in the face of an American social and economic landscape marked by deeply entrenched racial inequality? Specifically, how have the champions of that ideal accounted for the gulf between their theory and the conspicuous racial disparities that have resulted from its application? To answer these questions is to explain how an equality regime plagued by such glaring contradictions has displaced the goal of eradicating inequality as the prevailing paradigm of civil rights enforcement.

Colorblindness proponents could attribute such contradictions to the long shadow of historical subordination under which blacks as a class have continued to labor. Such an accounting, however, would cast serious doubt on whether colorblindness actually operates as a vehicle of racial equality. Instead, the internal logic of the colorblindness model itself has provided an appealing alternative explanation: If the raceneutral marketplace functions as a competitive meritocracy, justly distributing rewards according to individual desert, then by implication it also acts as a testing ground of merit, accurately measuring the relative talent, effort, skill, or ability of individual competitors. To the extent that such outcomes are, in aggregate, distributed in group-salient patterns, they do not impugn the fairness of the colorblind marketplace, but rather reflect real differences between groups.

These avowed racial egalitarians have learned to talk about those differences, in turn, by embracing a burgeoning body of social scientific theory on American ethnic dynamics. This Article argues that by recasting African Americans as just one among the nation's many "ethnic groups," colorblindness proponents-including a majority of the Supreme Court-have forged the trope of black ethnicity into a distinctly modern, politically respectable, and ostensibly anti-racist account of racial difference in which most racial inequality lies beyond the scope of antidiscrimination law..$^{9}$ Moreover, it is an account that, by emphasizing the historical and cultural—as opposed to "natural" or "genetic"-sources of group difference, has resonated with both

of particular groups seem regularly to come out at the bottom." Morton J. Horwitz, The Jurisprudence of Brown and the Dilemmas of Liberalism, 14 HARV. C.R.-C.L. L. REV. 599, 608 (1979),

9. Robert Post provides a productive framework for thinking about the interaction between "culture," understood as "the beliefs and values of nonjudicial actors," and the development of legal doctrine. Robert C. Post, Forward: Fashioning the Legal Constitution: Culture, Courts, and Law, 117 HARV. L. REV. 4, 8 (2003). Although Post's analysis is addressed specifically to constitutional law, while this Article is addressed equally to the Supreme Court's rendering of Title VII, his formulation remains apt. "[C]onstitutional law and culture are locked in a dialectical relationship," Post explains, "so that constitutional law both arises from and in turn regulates culture.... [T] Court in fact commonly constructs constitutional law in the context of an ongoing dialogue with culture, so that culture is inevitably (and properly) incorporated into the warp and woof of constitutional law." Id. 
mainstream civil rights and multiculturalist discourses.

Scholarly critics of the colorblindness model of racial equality have noted its appropriation of ethnicity theory, and argued that it amounts to an inconsistent, and even contradictory, approach to race. The legal and intellectual coherence of an equality regime that obliges decisionmakers to disregard race, they point out, paradoxically has become dependent on an auxiliary logic of racial difference. ${ }^{10}$ This Article builds on this insight but argues that it misstates the nature of the paradox. In fact, colorblindness proponents have appropriated the new racialism of black ethnicity not in spite of their genuine commitment to liberal, individualistic, race-neutral egalitarianism, but rather precisely because of it. By reducing the meaning of legal equality to the racially neutral treatment of individuals, policymakers and courts effectively generated ascriptions of racial difference. If this analysis proves compelling, moreover, it casts doubt on the Supreme Court's most forceful moral argument for subjecting all racial classifications to strict constitutional scrutiny: that racial classifications "can only exacerbate rather than reduce prejudice," 11 and that only by prohibiting such classifications can we achieve "an equality that will make race irrelevant." 2 This Article maintains that not only is colorblind competition a poor remedy for the ongoing effects of past racial subordination; it is an implausible, and even counterproductive, antidote for the reproduction of racialism itself.

Part I explores the conceptual landscape of antidiscrimination law in the formative decade of civil rights enforcement. It demonstrates that in the wake of the 1964 Act, civil rights activists, federal officials, and the Supreme Court alike routinely presumed that in the absence of unlawful discrimination, African Americans and other racial minorities would enjoy important social and economic goods roughly in proportion to their membership in the population. More recent controversy over racial

10. See, e.g., John O. Calmore, Exploring Michael Omi's "Messy" Real World of Race: An Essay for "Naked People Longing to Swim Free," 15 LAW \& INEQ. 25 (1997); Gotanda, supra note 5; Cheryl I. Harris, Equal Treatment and the Reproduction of Inequality, 69 FORDHAM LAW REVIEW 1753 (2001); John E. Morrison, Colorblindness, Individuality, and Merit: An Analysis of the Rhetoric Against Affirmative Action, 79 lowA L. REV. 313 (1994); Siegel, Discrimination, supra note 3; Reva B. Siegel, The Racial Rhetorics of Colorblind Constitutionalism: The Case of Hopwood v. Texas, in RACE AND REPRESENTATION: AfFiRmative ACTION (Robert Post \& Michael Rogin, eds. 1998). All of these studies, this one included, have profited from Michael Omi and Howard Winant's indispensable treatment of the issue in their landmark RACIAL FORMATION IN THE UNITED STATES, supra note 5.

11. Adarand, 515 U.S. at 229 (quoting Fullilove v. Klutznick, 448 U.S. 448,545 (1980) (Stevens, J., dissenting)).

12. Croson, 488 U.S. at 527 (Scalia, J., concurring). See also id. at 495 (arguing that to subject racial classifications to anything less than strict scrutiny would "assure[] that race will always be relevant in American life"); Adarand, 515 U.S. at 241 (Thomas, J., concurring) (arguing that the "racial paternalism" affirmative action programs "stamp minorities with a badge of inferiority"). 
preferences has obscured the extent to which this presumption of racial proportionality shaped both early Title VII enforcement and equal protection law.

Part II analyzes an intellectual sea change in how the Supreme Court, in concert with a host of influential public intellectuals and political writers, accounted for racial inequality in the $1970 \mathrm{~s}$ and $1980 \mathrm{~s}$. It documents the joint ascendancy of the paradoxical yet mutually enforcing discourses of colorblind competition and black ethnic difference, and demonstrates how colorblindness proponents recast the meaning of conspicuous racial underrepresentation, from a potentially actionable measure of illicit discrimination to a morally benign legal irrelevancy.

Part III then demonstrates how the Burger and Rehnquist Courts assimilated the "black ethnicity" critique of racial proportionality into three important domains of civil rights jurisprudence: the "disparate impact" action under Title VII; racial preferences in public construction contracting; and affirmative action in higher education. That critique supplied the essential rationale with which the Court disavowed the pursuit of racially proportionate representation as a guiding value of American antidiscrimination law. As a result, by the end of the 1980s a new consensus had emerged that to enlist federal antidiscrimination law to that end would contravene the proper scope of both the Fourteenth Amendment and the 1964 Act.

\section{Racial Proportionality IN THE Civil Rights ERA}

In 1963, the Southern Christian Leadership Conference (SCLC) launched a broad-based economic development program called Operation Breadbasket. Martin Luther King, Jr. explained to an audience of SCLC members a few years later that the program centered on consumer boycotts of local stores and industries that excluded blacks from meaningful job opportunities. It was, he stated, "a very simple program, but a powerful one.... It simply says that we will no longer send our money where we can not get substantial jobs." 13 By way of illustration, King recounted a recent visit to a large Cleveland dairy producer. When he "went to get the facts about their employment," King "discovered that they had 442 employees and only 43 Negroes, yet the Negro population of Cleveland is thirty-five percent of the

13. Martin Luther King, Jr., "Where Do We Go From Here?" Annual Report Delivered at the Eleventh Convention of the Southern Christian Leadership Conference (August 16, 1967) (transcript on file with author). 
total ... ."14 The injustice reflected in such numbers was manifest.

It was painfully self-evident to King and his audience that the dramatic underrepresentation of blacks among local dairy employees represented a civil rights problem. After all, why would one doubt that, but for pervasive racial discrimination, Cleveland blacks would have held the dairy jobs roughly in proportion to their membership in the local population? In the early years of civil rights enforcement, this presumption of racial proportionality directly and explicitly informed not only civil rights activism, but also federal antidiscrimination law relating to employment, school desegregation, and voting. In marked contrast to the conventional wisdom of the post-civil-rights era, for the generation of activists, legislators and judges that made the Second Reconstruction, "equality of opportunity" and "equality of results" represented complementary, rather than divergent, aspirations. ${ }^{15}$

\section{A. Federal Enforcement of the Antidiscrimination Mandate, 1965-1971}

Modern judges and legal commentators across the political spectrum routinely understand Title VII of the 1964 Act to be the cardinal expression of a pure disparate treatment regime, in which racial inequality unaccompanied by evidence of intentional discrimination is legally irrelevant. ${ }^{16}$ For the coalition of civil rights activists and liberal

14. Id.

15. In contemporary rubric, "equality of opportunity" is typically used to mean procedural colorblindness, in which the injunction against treating an applicant or employee unfavorably on account of her race is scrupulously enforced, and each individual is thus judged solely on the basis of her merit. "Equality of results," by contrast, is used to describe a process in which decisionmakers employ racial preferences in order to achieve a pre-designated racial distribution of some desired good-jobs, or admissions to a university, for example - and in which each individual is evaluated on the basis of her membership in a particular racial group instead of, or at least in addition to, her merit. The issue of racial preferences has dominated the public debate. Conservatives and opponents of affirmative action decry the pursuit of racial proportionality as heavy-handed governmental "social engineering." See, e.g., Grutter v. Bollinger, 539 U.S. 306, 349, 355, 372 (2003) (Thomas, J., dissenting) (condemning university administrators' "meddling" attempts at "racial balancing" as part of a misguided project of "social experiments"). Even judicial defenders of racial preferences today tend to disavow the goal of racial representation, instead justifying such measures as a means to enhance racial "diversity." See, e.g., Grutter, 539 U.S. at 329-30 (distinguishing the compelling state interest of achieving student body "diversity" from constitutionally impermissible "racial balancing"). See infra text accompanying notes 128-151, and 185-208.

16. Indeed, to the modern ear Title VII sounds loudly and clearly in the language of colorblindness. The bill's authors not only resisted pleas from some civil rights advocates to require employers to redress racial imbalances in their workforces, if necessary through racial preferences; in Section 703(j), added to pacify the bill's critics, they expressly disavowed such a purpose:

Nothing contained in this title shall be interpreted to require any employer... to grant preferential treatment to any individual or to any group because of the race, color, 
policymakers responsible for the passage and enforcement of the 1964 Act, however, the unambiguous purpose of Title VII was both to eradicate unequal treatment and to bring about black economic equality. ${ }^{17}$

In the period between 1965 and 1971, Justice Department lawyers, EEOC administrators, civil rights advocates, and ultimately the federal courts transformed racial proportionality from a latent value and hopedfor result of antidiscrimination enforcement, to an affirmative goal of the nation's new equality regime. Legal scholars typically interpret this transformation as a real, though short-lived, ascendancy of what is sometimes called an "antisubordination" theory of legal equalitycharacterized by a concern with providing corrective justice to

religion, sex, or national origin ... on account of an imbalance which may exist with respect to the total number or percentage of persons of any race . . employed by an employer ... in any community, state, section, or other area, or in the available work force....

Civil Rights Act of 1964, Pub. L. No. 88-352 § 703(j), 78 Stat. 241, 257 (1964) (codified in 42 U.S.C. $\S 2000 \mathrm{e}-2(\mathrm{j})(2000)$. The bill's Senate sponsors circulated a detailed document, known as the "ClarkCase memorandum" (after Senate floor managers Joseph Clark (D-PA) and Clifford Case (R-NJ)), reassuring critics that to require an employer to achieve a "racial balance" in its workforce would itself be a violation of Title VII. 110 CONG. REC. 7213 (April 8, 1964).

17. Indeed, even as the Clark-Case memorandum insisted that the Senate bill recognized only an individual right to equal employment opportunity, it also emphasized that "the presence of other members of the same minority group in the workforce may be a relevant factor in determining if in a given case a decision to hire or refuse to hire was based on race . . ." 110 CONG. REC. 7213 (April 8, 1964). If the identification of statistical disparities in an employer's workforce was the most efficient way to detect a pattern of discrimination, the memorandum explained, state laws proscribing the identification of a person's race on employment applications-a hallmark achievement of the northern states' uneven yet progressive embrace of colorblindness in the $1940 \mathrm{~s}$ and $1950 \mathrm{~s}$-would have to yield to the need for racial data. As a result, many seasoned civil rights advocates reevaluated their unconditional commitment to colorblindness. As the Urban League's Edwin Berry testified, "in the early 1940s, when the great drive was to get race off the records, I was one of the leaders in it. I was hollering the loudest, and now I apologize for having done it because I think it was a mistake." House Committee on Education and Labor, Equal Employment Opportunity: Hearings Before the Special Subcommittee on Labor of the Committee on Education and Labor, 87th Cong. 322 (1962) (quoted in PaUl D. MORENo, From DiRect action to AFFirmative ACTION: FaIR EMPLOYMENT LAW AND POLICY IN AMERICA, 1933-1972, 201). See generally HUGH DAVIS GRAHAM, THE CIVIL RIGHTS ERA: ORIGINS AND DEVELOPMENT OF NATIONAL POLICY, 1960-1972 117-19 (1990).

Some proponents of the Act reasoned that because pervasive race discrimination was the direct and unambiguous cause of black economic equality, purging the nation's employment system of discriminatory practices would, in due course, result in something approximating racially proportionate representation. As sociologist John David Skrentny explains, for the architects of Title VII the colorblindness model was "derived from a taken-for-granted principle of causality ... that a fair and equal society will naturally occur when people are free." JOHN DAVID SKRENTNY, THE IRONIES OF Affirmative ACtion: POlitics, Culture AND JuStice IN AMERICA 15 (1996). When Congress enacted the colorblindness model into law, it thus did so "with the belief or expectation that freedom from discrimination would bring about black equality [and] comparable statistical rates of black and white employment and unemployment." Id. That is to say, one of the key aspirations of the new colorblindness regime was to bring about "equality of results." 
discriminated-against groups-over an "anticlassification" theorycharacterized by a concern with ensuring procedural colorblindness. Accordingly, progressive constitutional scholars have celebrated this period as a triumph of substantive equality over the conservative formalism of the colorblindness model. For such scholars, this body of jurisprudence represents the high-water mark of race equality law, against which the Supreme Court's subsequent retreat should be measured. ${ }^{18}$ Conservatives, by contrast, have condemned the growing race-consciousness of the period as a betrayal of what they see as the pristine colorblindness mandate of Brown and the 1964 Act. ${ }^{19}$ Although this neat analytical division of antidiscrimination theory into distinct, competing principles or ideological camps has been indispensable in clarifying the meaning and stakes of different conceptions of racial equality, it does not accurately account for how ideas about equality and discrimination actually unfolded over time. ${ }^{20}$

Racial proportionality emerged as a central, express value of American antidiscrimination law as a direct result of the colorblindness model's failure to meet increasingly urgent demands for racial justice. Prior to and immediately following the adoption of Title VII, policymakers and civil rights officials had viewed conspicuous racial underrepresentation as compelling evidence of intentional discrimination. Within a few short years, government lawyers, civil rights activists, and courts had expanded the potential probativeness of racial underrepresentation outward, from identifying patterns of disparate treatment by a particular employer or industry to detecting the effects of "institutional" or "societal" discrimination. Crucially, the absence of racial proportionality said something about an employer, an industry, or an institution.

\section{Racial Underrepresentation as "Sociological Radar"}

Title VII's enforcement structure conceded much to the Act's critics. Perhaps most significantly, it denied the Equal Opportunity Employment Commission (EEOC) - the federal agency responsible for enforcing Title VII-the authority to issue cease-and-desist orders or to sue in

18. See, e.g., Fiss, supra note 4; Freeman, supra note 3; Michael Klarman, An Interpretive History of Modern Equal Protection, 90 MICH. L. REV. 213 (1991); Strauss, supra note 4.

19. See, e.g., Morris B. Abram, Affirmative Action: Fair Shakers and Social Engineers, 99 HARV. L. REV. 1312 (1986); Terry Eastland, The Case Against Affirmative Action, 34 WM. \& MARY L. REV. 33 (1992).

20. See Jack M. Balkin \& Reva B. Siegel, The American Civil Rights Tradition: Anticlassification or Antisubordination?, 58 U. MIAMI L. REV. 9 (2003) (demonstrating how antisubordination values have often shaped courts' application of the anticlassification rule). 
federal court. The consignment of the EEOC to combating discrimination through persuasion and consultation, and by providing assistance to individual complainants, represented a distinct defeat for fair employment advocates. Yet the Act did enable the United States Attorney General to bring pattern or practice suits, thus preserving at least the potential for the kinds of wholesale actions preferred by the civil rights community. ${ }^{21}$ Whether or not such potential would be fulfilled, however, depended more on the will of the Attorney General and the solicitousness of the federal courts than on Title VII's text.

From the beginning, the federal administrators and lawyers responsible for enforcing Title VII understood the limitations of the individual-complaint-centered approach, and actively developed more ambitious alternatives. For the Justice Department, as well as the overburdened and understaffed EEOC, the identification of statistical disparities in the racial composition of a given workforce was essential to the enforcement of Title VII's injunction against intentional discrimination. The EEOC required every employer in its jurisdiction to complete a racial reporting form disclosing the race of each of its employees. EEOC advisor Alfred Blumrosen described the racial statistics thus obtained as a vital form of "sociological radar," which would enable the agency to identify patterns of disparate treatment. ${ }^{22}$ As Blumrosen explained, racial reporting was

perhaps the most important tool in any program to eliminate employment discrimination. Here were lists of major employers excluding minorities in a massive way which outraged any reader of the statistics .... Here at last was a basis for government-initiated programs which were not based on complaints and which could focus on possible potential discriminators effectively .... There was a perennial shortage of manpower and money in antidiscrimination programs. If government could focus, through the reporting system, on those employers where underutilization was sharpest, there was a possibility of successfully combating discrimination. $^{23}$

For Blumrosen and the pragmatic officials who staffed the EEOC and the Justice Department's Civil Rights Division, proceeding on the assumption that gross racial disparities were often probative of discriminatory intent was both intellectually uncontroversial and practically essential. The unstated but indispensable premise of this approach was that in the absence of disparate treatment, racial minorities would be represented more or less proportionally.

21. GRAHAM, supra note 17 , at 189-91.

22. ALFRED BLUMROSEN, BLACK EMPLOYMENT AND THE LAW 68 (1971).

23. Id. at $68-69$. 
As it was employed in the early years of Title VII enforcement, the sociological radar approach thus yoked the presumption of racial proportionality to the pursuit of colorblindness in a way that will strike many contemporary readers as paradoxical. Although sociological radar unambiguously entailed a form of color consciousness, it was a color consciousness to be undertaken not by the employers under the Act's jurisdiction, but rather by Title VII's enforcers. Proportionality thus operated both as a key strategic premise and an expected consequence of the enforcement of equal treatment, even as the requirement that plaintiffs prove discriminatory intent remained conceptually intact.

The intent requirement itself, however, came under increasing pressure from the weight of necessity. A wave of devastating race riots combined with the progressively more radical inflection of the civil rights movement to impress on national policymakers a new sense of urgency around the problem racial inequality in employment. ${ }^{24}$ In his famous and controversial 1965 report, "The Negro Family," issued months before the first of the major riots, presidential advisor Daniel Moynihan postulated that the "principle challenge of the next phase of the Negro revolution is to make certain that equality of results will now follow. If we do not, there will be no social peace in the United States for generations." ${ }^{25}$ Within a few short months, a mounting urban crisis confirmed the prescience of Moynihan's prediction. Civil rights leaders and a politically diverse cast of national policymakers interpreted the riots as a symptom of blacks' frustration with chronic joblessness and poverty. "[T]he lesson of the revolution of rising expectations," Vice President Hubert Humphrey instructed, was that " 20 million Americans will no longer be pacified by slogans or tokens."26 The colorblindness model of racial equality, only recently codified in the 1964 Act, increasingly struck many observers as inadequate and even naïve. ${ }^{27} \mathrm{As}$

24. Each summer from 1964 to 1968 , government officials and the American public watched as violent outbursts wracked the nation's cities. Notably, the vast majority of the violence occurred not in the historic bastions of white supremacy - the Jim Crow South-but in the nation's presumably more tolerant northern cities. Tens of thousands of blacks participated in hundreds of riots, looting businesses, destroying buildings, and engaging in violent clashes with police and civilians. Although Watts, in July 1964, and then Detroit and Newark, in the "long hot summer" of 1967, witnessed the most spectacular and catastrophic episodes, hundreds of smaller cities across the country also experienced unprecedented eruptions. The disturbances were responsible for more than 200 deaths and several thousand injuries. See Allen J. Matusow, The UnRaveling of America (1984); LuCAs A. Powe, JR., THE WARREN COURT AND AMERICAN POLITICS 274-76 (2000).

25. Daniel Patrick Moynihan, The Negro family: The Case for National action 3 (U.S. Dep't of Labor 1965).

26. “To Fulfill These Rights," Opening Meeting, White House Conference (June 1, 1966), in Michael R. Belknap, ED, 2 Civil Rights, The White house and the Justice Department 153 (1991).

27. As Bayard Rustin noted in 1965 , increasingly at issue in the civil rights movement was "not 
Moynihan put it, the civil rights coalition's demand for equality of opportunity "is not (or at least no longer) a demand for liberty alone, but also a demand for equality-in terms of group results." ${ }^{28}$ Racial proportionality thus evolved from a strategic premise in, and expected consequence of, the pursuit of colorblindness, to an end in itself, parallel to but analytically independent from the injunction against disparate treatment. ${ }^{29}$

\section{Racial Proportionality as an End in Itself: The Philadelphia Plan}

Civil rights advocates and federal officials moved seamlessly from using racial statistics to probe the intent behind various employment practices to policing the racial results of those practices. The federal government's campaign to integrate the construction industry illustrates the conceptual and legal contiguity of what subsequently became understood as competing modes of civil rights enforcement. Historically, the construction industry was suffused with a seemingly intractable culture of both overt and informal discrimination, and was notoriously hostile to blacks' demands for fair access to the lucrative skilled trades. ${ }^{30}$ The culturally exclusive dimension of the building trades made it a particularly elusive target for antidiscrimination enforcement. When trades unions were charged with racial

civil rights, strictly speaking, but social and economic conditions." Bayard Rustin, From Protest to Politics: The Future of the Civil Rights Movement, 39 COMMENT. 25, 26 (1965). The civil rights movement was "now concerned not merely with removing the barriers to full opportunity but with achieving the fact of equality." Id. at 27.

28. MOYNIHAN, supra note 25 , at 3.

29. Federal civil rights administrators developed modes of antidiscrimination enforcement that placed increasingly direct pressure on employers to achieve racially balanced workforces. For example, the EEOC held a series of hearings to examine the employment practices of industries in which blacks were statistically underrepresented, according to the racial data obtained from the EEO-1 forms. The express purpose of the hearings was not only to purge suspect industries and employers of intentional discrimination, but to "remedy" racial imbalances in their workforces by pressuring employers to achieve statistically proportionate minority "utilization." SKRENTNY, supra note 17, at 132-33. Such strategies extended the probative logic of statistical underrepresentation-from the intent of individual employers, to the social, historical, and institutional disadvantages under which blacks competed in the newly "colorblind" employment market.

30. For most of the twentieth century, explains historian Thomas Sugrue, the "building trades [were] a textbook example of the employment niche, a sector of the economy dominated by a single group and characterized by a long history of exclusion of competing groups." Thomas J. Sugrue, Breaking Through: The Troubled Origins of Affirmative Action in the Workplace, in COLOR LINES: AfFiRmative ACTION, IMMigration, AND CIVIL Rights Options fOR AMERICA 41, 41 (John David Skrentny ed., 2001). One's trade was commonly understood not only as a source of income, but also as "a form of property, ... to be passed from father to son." Id at 43. In this context, many white workers viewed the federal government's new efforts to enhance blacks' economic opportunities as a direct threat to this entitlement. They especially feared that compelled racial integration would undermine the seniority system —one of the cardinal achievements of the twentieth-century labor movement. 
discrimination, they typically defended their racial exclusivity by pointing to their long-standing practice of recruiting new members through family, ethnic, religious, and communal networks, and arguing that blacks simply did not apply for the positions at issue. ${ }^{31}$ Such a defense proved difficult to answer within the strict confines of the colorblindness framework.

To combat this industry-wide intransigence, President Johnson established the Office of Federal Contract Compliance (OFCC), in a September 1965 executive order. ${ }^{32}$ Lodged within the Department of Labor, the new agency was responsible for insuring non-discrimination among federal construction contractors. Like the EEOC, the OFCC faced the daunting challenge of reforming a set of institutional and cultural arrangements that virtually excluded blacks, but from which hard proof of disparate treatment was extraordinarily difficult to obtain.

The OFCC, however, differed from the EEOC in at least two important respects. First, because the OFCC was created under Title VI, rather than Title VII, of the 1964 Act, it was not subject to Section 703(j)'s enforcement constraints disallowing federal administrators from requiring employees to remedy racial "imbalances" in their workforces through "preferential treatment." 33 Second, the OFCC's enforcement leverage came from its authority to attach special conditions of nondiscrimination to valuable federal construction contracts. ${ }^{34}$ These distinctive aspects of the OFCC's legal and institutional position emboldened agency administrators to extend the logic of the EEOC's "sociological radar" approach, and ultimately to define discrimination in terms that bypassed the intent requirement altogether.

The OFCC launched a series of metropolitan-area-based initiatives in four "special program areas," including St. Louis, San Francisco, Cleveland, and Philadelphia. The "Philadelphia Plan," the most ambitious and controversial of the OFCC's programs, quickly became the agency's signature enterprise. The Plan not only required that government contractors cease discriminating; it also instituted a "preaward approach" under which successful bidders were obliged to provide hiring plans that achieved designated levels of minority group representation within each component of a given construction project. Federal contractors and their unions were required to adopt specific goals and timetables to correct the racial imbalances in their

31. Id. at 44.

32. Exec. Order No. 11246, 30 Fed. Reg. 12319 (Sept. 28, 1965).

33. See supra note 14.

34. Terry H. ANDERson, The Pursuit of Fairness: A History of AFFirmative ACtion 105 (2004). 
workforces. $^{35}$

Notably, President Nixon's Labor Department embraced, and arguably even extended, an enforcement logic that emphasized the achievement of "results" over merely purging employers' and unions' decisionmaking processes of discriminatory intent. ${ }^{36}$ As Assistant Secretary of Labor Arthur Fletcher explained, "[v]isible, measurable goals to correct obvious imbalances [were] essential." 37 After Congress tacitly endorsed the Philadelphia Plan, ${ }^{38}$ Secretary of Labor George Shultz signed an order extending the policy beyond the construction industry to all companies doing business with the federal government. ${ }^{39}$

\section{B. Racial Proportionality in the Lower Federal Courts}

By the end of the 1960s, the federal courts had imbued the meaning and scope of Title VII with the logic of racial proportionality. An inauspicious series of early district court decisions held that a statistical disparity between the racial composition of a labor union or company workforce and that of the local population did not, by itself, constitute a prima facie showing of discrimination. ${ }^{40}$ Led by the Fifth Circuit, the federal courts of appeals responded with a series of opinions that largely vindicated the Justice Department's ability to attack employment practices that, though racially neutral on their face, had the clear effect of excluding vastly disproportionate numbers of blacks. Following Blumrosen and others at the EEOC and Justice Department, the federal

35. Id.

36. Historians disagree over whether Nixon supported the Philadelphia Plan out of a sincere desire to end discrimination and enhance black economic opportunity, or as part of his "southern strategy" to capture the votes of southern whites. Substantial evidence exists for both arguments. Whatever Nixon's initial motives, however, by the 1970 s, at least part of the reason for his continued support of the controversial program clearly lay in its having driven a wedge between two key Democratic Party constituencies-African Americans and organized labor. For an informative treatment of Nixon's support of the Philadelphia Plan, and his record on civil rights more generally, see DeAn J. Kotlowski, Nixon's Civil Rights: Politics, Principle, AND POLICY 97-124 (2001).

37. ANDERSON, supra note 34, at 117.

38. Congress expressed its views on the Philadelphia Plan only indirectly. After the United States Comptroller ruled that the program violated Title VII, Attorney General John Mitchell, on questionable legal authority, overruled the Comptroller's decision. In response, a coalition of conservative Republicans and southern Democrats introduced an appropriations rider that would have made the Comptroller's judgment unreviewable by the Attorney General. At the strong urging of the White House, Congress defeated the rider. See ANDERSON, supra note 34, at 115-24.

39. ANDERSON, supra note 34, at 124-25.

40. See, e.g., United States v. Sheet Metal Workers Int'l Ass'n., Local 36, 280 F.Supp. 719, 728 (E.D. Mo. 1968) ("Mere absence of Negroes in a particular group does not constitute proof of pattern or practice of discrimination."); United States v. Hayes Int'l Corp., 295 F.Supp. 803, 808 (N.D. Ala. 1968) ("The Civil Rights Act of 1964 was not intended to penalize unions or others for their sins prior to the effective date of the Act ...."). 
courts embraced the inferential logic that underlay the sociological radar approach: In the absence of discrimination, blacks would be represented in desirable jobs roughly in proportion to their membership in the local workforce; therefore, significant racial underrepresentation in a given job category raised a strong suspicion of intentional discrimination. "In racial discrimination cases," explained the Tenth Circuit, "statistics often demonstrate more than the testimony of many witnesses, and they should be given proper effect by the courts." ${ }^{, 41}$

More challenging to courts than the meaning of racial statistics per se, however, was a cluster of employment practices that disproportionately excluded blacks from particular job categories, but which betrayed little or no direct evidence of discriminatory intent. ${ }^{42}$ Perhaps the most difficult and controversial question was whether and to what extent the 1964 Act would curb white employees' seniority rights that had "vested" during the era of overt racial discrimination. The issue presented an archetypal conundrum: How to reconcile Title VII's insistence on equal employment opportunity with the serious competitive disadvantages that, as the result of generations of discrimination, blacks as a class brought to the employment market. Two seminal 1968 district court decisions-Quarles $v$. Phillip Morris, ${ }^{43}$ and United States $v$. Papermakers ${ }^{44}$-made clear that the courts' resolution of the question

41. Jones v. Lee Way Motor Freight, Inc., 431 F.2d 245, 247 (10th Cir. 1970). For additional examples of appellate decisions accepting the probative value of racial statistics, see Parham $v$. Sw. Bell Tel. Co., 433 F.2d 421, 426 (8th Cir. 1970); United States v. Int'l. Bhd of Elec. Workers, Local 38, 428 F.2d 144 (6th Cir. 1970); United States v. Sheet Metal Workers Int'l Assn., Local Union 36, 416 F.2d 123 (8th Cir. 1969); Local 189, United Papermakers \& Paperworkers v. United States, 416 F.2d 980 (5th Cir. 1969); United States v. Hayes Int'l Corp., 415 F.2d 1038 (5th Cir. 1969). See also SKRENTNY, supra note 17 , at $162-63$.

42. Employers routinely required that job applicants pass aptitude tests or fulfill educational requirements, for example, even though black applicants had received systematically inferior educations. See, e.g., Griggs v. Duke Power Co., 292 F.Supp. 243 (M.D. N.C. 1968). Before the Supreme Court concluded in 1971 that such practices were actionable under Title VII (see Griggs v. Duke Power Co., 401 U.S. 422 (1970)), the lower federal courts were sharply divided. Several courts held in 1969 and 1970 that a testing or educational requirement that lacked an "overriding legitimate business purpose" and which, in effect, "locked" incumbent black employees into traditionally black departments, constituted prohibited discrimination within the meaning of Title VII. See Braussard v. Schlumberger Well Serv., 315 F.Supp. 506, 510 (S.D. Tex. 1970). See also Penn v. Stumpf, 308 F.Supp. 1238 (N.D. Cal. 1970); United States v. Georgia Power Co., 1970 WL 162 (N.D. Ga. Sept. 22, 1970). Other courts agreed in principle with that rule, but when evaluating whether a testing or educational requirement was sufficiently related to a legitimate business purpose they applied such a liberal standard that virtually any facially neutral practice stood a good chance of surviving review, no matter how racially unequal its result. The leading authority for this line of cases was Griggs v. Duke Power Co., 420 F.2d 1225 (4th Cir. 1970). See also Colbert v. H-K Corp., 1970 WL 120 (N.D.Ga. July 6, 1970); United States v. Nat'I Lead Co., 315 F.Supp. 912 (E.D. Mo. 1970).

43. 279 F.Supp 505 (E.D. Va. 1968).

44. Local 189, United States v. United Papermakers \& Paperworkers, 282 F.Supp. 39 (E.D. La. 1968) (hereinafter "Papermakers I"). 
would carry far-reaching implications across a broad range of social and institutional contexts. At issue, as the Quarles court saw it, was whether "the present consequences of past discrimination [were] covered by the act[.]"

As the courts of appeals took up Quarles and Papermakers, they adopted a set of interpretive doctrines that further built the presumption of racial proportionality into the legal machinery of Title VII enforcement. $^{46}$ The Fifth Circuit's decision in Papermakers is illustrative. Throughout his opinion, Judge John Minor Wisdom skillfully fused the question of whether the defendant union and employer had intended to discriminate with the documented racial results of the challenged employment practice. In so doing, he subtly transformed the legal meaning of "discrimination" under Title VII. At least two elements of Wisdom's reinterpretation warrant special notice. First, the opinion suggested that where an employment practice, though neutral on its face, has the "inevitable effect" 47 of maintaining blacks as a class in an inferior status, the racial results of that practice were compelling evidence that the defendant had intended to discriminate. ${ }^{48}$

Second, Wisdom suggested that when a post-Act employment practice perpetuated the racial results of admittedly intentional pre-Act discrimination, the pre-Act intent to discriminate would be imputed to the post-Act practice. Because the choice to continue the seniority system "was not accidental," in the sense that "the defendant meant to

45. Quarles, 279 F.Supp at 516. Prior to July 1, 1965-the effective date of Title VII-the defendant employer in each case had maintained an overtly racially segregated workforce. Black and white employees had occupied entirely separate labor departments, each with its own union, seniority roster and job progression ladder. When the employers stopped hiring and assigning employees on the basis of race, incumbent black employees became newly eligible to transfer from their lower-paid, formerly all-black department to a higher-paid, formerly all-white department. Yet because the pre1965 seniority rosters remained in operation, a black employee could undertake such a transfer only at the cost of surrendering his accrued seniority, and thus "find[ing] himself junior to white employees holding less employment seniority who got their positions by reason of the company's formerly racially segregated employment policy." Id. at 514 . The court granted that the restrictive transfers policy might serve "legitimate management functions," $I d$. at 513 , including the promotion of efficiency, employee retention, and the reduction of necessary training. It nevertheless concluded that by maintaining a policy that so plainly transmitted past discrimination into present competitive disadvantage, the defendants had "intentionally engaged in unlawful employment practices by discriminating on the basis of race." Id. "Congress did not intend to freeze an entire generation of Negro employees into discriminatory patterns that existed before the act," the court explained. Id. at 516 .

46. For an informative discussion of this caselaw, see MORENO, supra note 17, at 236-61.

47. Local 189, United Papermakers \& Paperworkers v. United States, 416 F.2d 980, 988 (5th Cir. 1969) (hereinafter "Papermakers II").

48. Quoting directly from Dobbins v. Local 212, 292 F.Supp. 413 (S.D.Ohio 1968), another seniority case, Judge Wisdom declared that "the requisite intent may be inferred from the fact that the defendants persisted in the conduct after its racial implications had become known to them." Papermakers II, 416 F.2d at 997. 
do what he did," a court effectively could import the defendant's pre-Act intention into its post-Act state of mind. ${ }^{49}$

Perhaps most tellingly, courts applying the "present effects" doctrine to procedurally race-neutral seniority systems tended to draw legal authority, not from employment discrimination cases, but from spheres of civil rights law addressing fundamental rights of citizenship-voting rights, school desegregation, and jury selection. As sociologist John David Skrentny notes, such spheres more readily lend themselves to the logic of proportionate representation because they are not subject to labor market values such as meritocratic competition and employer prerogative. $^{50}$

Notably, the Third Circuit looked outside the employment context to uphold the Philadelphia Plan's requirement that federal contractors achieve prescribed levels of minority representation in their workforces. The court rejected the plaintiff contractors' claim that the Plan's imposition of "remedial quotas" required employers to violate Title VII's prohibition against hiring or classifying employees on the basis of race. ${ }^{51}$ Noting the "obvious underrepresentation" 52 of minorities in the six Philadelphia-area construction trades at issue, the court concluded that " $[\mathrm{t}] \mathrm{o}$ read $\S 703$ (a) in the manner suggested by the plaintiffs we would have to attribute to Congress the intention to freeze the status quo and to foreclose remedial action under other authority designed to overcome existing evils." 53 "Clearly the Philadelphia Plan is colorconscious,",54 the court acknowledged. But "[i]n other contexts," the court instructed, citing to a school desegregation and housing discrimination case, ${ }^{55}$ "color-consciousness has been deemed to be an appropriate remedial posture." 56

49. In a significant concession to employers' concerns about business efficiency and managerial prerogative, Judge Wisdom drew a distinction between employment practices rooted in "discriminatory intention," and those that were "related to a reasonable economic purpose." Id. at 992 . "When the defendant's conduct evidences an economic purpose" he explained, "there is no discrimination under Title VII .... " Id.

50. SKRENTNY, supra note 17 , at 163.

51. Contractors Ass'n. of E. Pa. v. Sec'y. of Labor, 442 F.2d 159, 172-73 (3d Cir. 1971).

52. Id. at 173 .

53. Id.

54. Id.

55. See Offermann v. Nitkowski, 378 F.2d 22, 24 (2d Cir. 1967) (school desegregation); Norwalk CORE v. Norwalk Redev. Agency, 395 F.2d 920, 931 (2d Cir. 1968) (housing).

56. Contractors' Ass'n, 442 F.2d at 173. A number of Title VIl decisions similarly justified applying racial proportionality reasoning in the employment context by quoting a line from Alabama $v$. United States, 304 F.2d 583 (5th Cir. 1962), a pre-Civil Rights Act voting rights case: "In the problem of racial discrimination, statistics often tell much and Courts listen." Id. at 586 . For examples of such cases, see Parham v. Sw. Bell Tel. Co., 433 F.2d 421 (8th Cir. 1970); United States v. Ironworkers Local 86, 443 F.2d 544, 511 (9th Cir. 1971); EEOC v. United Assn. of Journeymen \& Apprentices, 311 
Despite their overt concern with statistically demonstrable racial results, these lower court decisions did not abandon the intent requirement; rather, they stretched it. By sanctioning the evidentiary value of racial statistics, they operationalized the presumption of racial proportionality. Race-salient results were probative of discrimination even when unaccompanied by a particularized showing of discriminatory intent precisely because courts presumed that in the absence of past or present discrimination, blacks would be represented in many job categories roughly in proportion to their membership in the population. The same logic underlay the courts' endorsement of the "present effects" doctrine, which brought within Title VII's reach employment practices that, but for their disparate racial impacts, were concededly racially neutral.

\section{Disparate Impact and the Supreme Court}

As we have seen, although the lower federal courts did construe Title VII to prohibit a variety of facially neutral employment practices bearing racially unequal results, they always interpreted the prohibited practices, however tenuously, as an instance of present disparate treatment on the basis of race. With its 1971 decision in Griggs v. Duke Power, the Supreme Court dethroned the intent requirement, unanimously announcing that "good intent or absence of discriminatory intent does not redeem employment procedures or testing mechanisms that operate as 'built-in headwinds' for minority groups ...." 57 Thus was born the disparate impact action-a conceptually distinct species of antidiscrimination law that did not depend on even an attenuated finding of discriminatory intent.

The basic architecture of the disparate impact action, which the Supreme Court elaborated in Griggs and its subsequent decisions, ${ }^{58}$ consists of three steps: First, a plaintiff must make a prima facie showing that a particular facially neutral employment practice-a hiring or promotion requirement, for example-excludes from consideration minority or women candidates at a disproportionately high rate. ${ }^{59}$ Second, once a plaintiff makes such a showing, the burden shifts to the defendant to prove that the challenged practice nevertheless is justified

F.Supp. 468, 471 (S.D.Ohio. 1970); Lea v. Cone Milsl Corp., 301 F.Supp. 97 (M.D. N.C. 1969). See also SKRENTNY, supra note 17, at 163-65.

57. Griggs v. Duke Power Co., 401 U.S. 424, 431-32 (1970).

58. The Court summarized the structure of the disparate impact action in Dothard v. Rawlinson, 433 U.S. 321,329 (1977).

59. Id. 
by "business necessity."60 Finally, if the defendant satisfies that burden, the plaintiff may still prevail if she can demonstrate that the employer could have met his workforce objectives through a less discriminatory alternative practice. ${ }^{61}$

The precise meaning of "business necessity" has generated vigorous debate, both on and off of the Supreme Court. Crucially, disparate impact analysis sometimes requires an employer who has no intention of discriminating to justify employment practices that traditionally have been part of a business owner's managerial prerogative, simply because they disqualify a disproportionately high percentage of minority or women candidates. Proponents of a "strict" standard of business necessity maintain that such practices should escape liability only if they are "essential" to measuring candidates' capacity to perform the job in question. $^{62}$ Proponents of a more permissive standard argue that such practices are justified by business necessity so long as they serve the employer's "legitimate" business goals. ${ }^{63}$ The stricter the definition of business necessity, the more strongly it imposes racial proportionality values on employers. And as we will see in this Section, in the years following Griggs the Court embraced a relatively strict standard.

Chief Justice Burger's opinion in Griggs has served as the primary doctrinal referent for all future disparate impact adjudication. The opinion itself contained a degree of ambiguity about the proper definition of business necessity. When an employment practice that was "fair in form" was shown to be "discriminatory in operation," Burger wrote, the "touchstone" of judicial review was "business necessity.",64 The Court's choice of the word "necessity," as well as its announcement that to survive review a discriminatory practice must "bear a demonstrable relationship to successful performance of the jobs for which it was used," 65 suggests that the Court intended to constrain

60. Id.

61. Id.

62. See, e.g., Susan Grover, The Business Necessity Defense in Disparate Impact Cases, 30 GA. L. REV. 387 (1996); D. Marvin Jones, No Time for Trumpets: Title VII, Equality, and the Fin de Siecle, 92 MICH. L. REV. 2311 (1994); George Rutherglen, Disparate Impact Under Title VII: An Objective Theory of Discrimination, 73 VA. L. REV. 1297 (1987).

63. See, e.g., Paul N. Cox, On A Blindered Impact Model: A Response, 46 DEPAUL L. Rev. 265 (1997); Michael Evan Gold, Griggs' Folly: An Essay on the Theory, Problems, and Origin of the Adverse Impact Definition of Employment Discrimination and Recommendations for Reform, 7 INDUST. REL. L.J. 429 (1985). Other commentators have advocated a variable standard, depending on the type of employment at issue. See, e.g., Andrew Spiropoulos, Defining the Business Necessity Defense to the Disparate Impact Cause of Action: Finding the Golden Mean, 74 N.C. L. REV. 1479 (1996).

64. Griggs, 401 U.S. at 431.

65. Id. The Court explicitly endorsed the strict EEOC Guidelines regarding personnel tests: "These guidelines demand that employers using tests have available "data demonstrating that the test is 
significantly employers' discretion to engage in such practices. Indeed, this is how most lower courts originally interpreted Griggs. ${ }^{66}$ Burger added, however, that job requirements operating as "built in headwinds" to minority candidates must have a "manifest relationship to the employment in question." ${ }^{, 67}$ Though this formulation does not necessarily detract from the Court's other, more forceful iteration of business necessity, it supplied language that opponents of a strict necessity requirement could, and later did, seize on to justify a lesser burden for defendants.

The Griggs Court evinced little hesitation in simply presuming that truly nondiscriminatory employment practices would usually result in racially proportionate representation; nor did it appear concerned that disparate impact analysis might conflict with employers' prerogatives to make market-rational hiring and promotion decisions. The Court dismissed the defendant's argument that the burden of proving business necessity would compel defendants to resort preemptively to hiring quotas. "Far from disparaging job qualifications as such," Burger explained, "Congress has made such qualifications the controlling factor, so that race, religion, nationality, and sex become irrelevant." And if opponents of robust disparate impact analysis were heartened by the Court's 1976 decision in Washington v. Davis, ${ }^{69}$ requiring plaintiffs asserting an equal protection violation to prove discriminatory intent, any hopes that the doctrinal effects of Davis would carry over to Title VII were dashed the following term, when the Court reaffirmed that in order to survive disparate impact review, a "discriminatory employment practice must be ... necessary to safe and efficient job performance."

predictive of or significantly correlated with important elements of work behavior which comprise or are relevant to the job or jobs for which candidates are being evaluated."' $I d$. at $434 \mathrm{n} .9$.

66. See, e.g., Jackson v. Seaboard Coast Line R.R. Co, 678 F.2d 992, 1016 (1 lth Cir. 1982); James v. Stockham Valves \& Fittings Co., 559 F.2d 310, 355 (5th Cir. 1977); Watkins v. Scott Paper Co., 530 F.2d 1159, 1168 (5th Cir. 1975).

67. Griggs, 401 U.S. at 333.

68. Id. at 436. Four years later, in Albermarle Paper Co. v. Moody, the Court confirmed what appeared to be a relatively strict definition of business necessity. The message of both Griggs and the EEOC Guidelines, the Court explained, was that "discriminatory tests are impermissible unless shown, by professionally acceptable methods, to be predictive of or significantly correlated with important elements of work behavior which comprise or are relevant to the job or jobs for which candidates are being evaluated." Albermarle Paper Co. v. Moody, 422 U.S. 405, 431 (1975) (quoting EEOC Guidelines).

69. 426 U.S. 229 (1976).

70. Dothard v. Rawlinson, 433 U.S. 321, 331 (1977). Dothard represents perhaps the high-water mark of the strict necessity standard. Although Dothard is a sex discrimination case, the Court no doubt formulated its reasoning with an eye toward race discrimination. The Court held unanimously that the State of Alabama's requirement that prison guards satisfy a minimum height and weight requirement-a requirement that disproportionately excluded women from employment as prison guards-constituted 
The unarticulated logical lynchpin of the strict necessity standard was the Court's expectation that truly meritorious evaluation processes would usually result in racially proportionate representation; in other words, that once employers removed unnecessary "headwinds" to minority opportunity, an appropriate racial "balance" would result without resort to "quotas." Notwithstanding its blow to the intent requirement, Griggs in fact represented an extension of, rather than a departure from, existing judicial common sense about how workplaces would look in the absence of discrimination.

\section{Racial Proportionality and Equal Protection: The Case of Construction Set-Asides}

The Supreme Court's constitutional review of federal affirmative action closely paralleled its construction of disparate impact under Title VII. Just as the presumption of racial proportionality underlay its relatively strict rendering of business necessity, so did it directly inform the Court's posture toward congressional attempts to redress the present effects of past discrimination among federal contractors. In the 1980 case of Fullilove v. Klutznick, the Court upheld against an equal protection challenge a congressional spending program requiring that ten percent of the funds granted to states and localities for public works projects be spent on supplies or services provided by minority business enterprises ("MBEs"). ${ }^{71}$ The question of whether the program was a valid exercise of Congress's Fourteenth Amendment enforcement powers turned on whether Congress had gathered sufficient evidence that state and local governments were engaged in construction procurement practices that, though racially neutral in form and intent, had a "discriminatory impact [by] perpetuating the effects of past discrimination." 72

Chief Justice Burger's opinion displayed remarkable deference toward Congress's purported factual basis for the MBE program. ${ }^{73}$ The Court cited approvingly a report of the House Subcommittee on Small Business Administration Oversight and Minority Enterprise,

sex discrimination in violation of Title VII because the State had failed to demonstrate that a particular level of physical strength (the purported justification for the requirement) was required to perform the job effectively. Id.

71. 448 U.S. 448 (1980).

72. Id. at 477 .

73. Such deference is all the more remarkable in light of the intense scrutiny to which the Supreme Court has subjected Congress' asserted factual basis for both Commerce Clause and Section V legislation over the past decade. See, e.g., United States v. Lopez, 514 U.S. 549 (1995); Adarand Constructors, Inc. v. Pena, 515 U.S. 200; United States v. Morrison, 529 U.S. 598 (2000). 
recommending that the House pass the legislation. ${ }^{74}$ Observing that MBEs realized only about .65 percent of all business receipts in the United States, the report concluded that "these statistics are not the result of random chance. The presumption must be made that past discriminatory systems have resulted in present economic inequalities." 75 "Although the Act recites no preambulatory "findings,", the Court resolved, "we are satisfied that Congress had abundant historical basis from which it could conclude that traditional procurement practices...could perpetuate the effects of prior discrimination." 76 Burger speculated that Congress must have considered the "marked disparity in the percentage of public contracts awarded to minority business enterprises" to have resulted not from "any lack of capable and qualified minority businesses, but from the existence and maintenance of barriers to competitive access which had their roots in racial and ethnic discrimination ... ."77 Under-representation alone, the Chief Justice reasoned, went a long way toward establishing the necessary factual predicate for the legislation.

The presumption of racial proportionality authorized the Court to infer conclusively from a showing of present racial underrepresentation that the disparity was the result of past discrimination. ${ }^{78}$ This was the constitutionally necessary evidentiary basis for any race-conscious congressional "remedy," and, crucially, it enabled policymakers to pursue increased minority participation without having to show specific institutional discrimination. The Supreme Court soon would adopt a markedly different view of how particular jobs were likely to be distributed in the absence of past discrimination, as the presumption of racial proportionality gave way to a narrative of racial stratification centering instead on ethnic group differences.

\section{COLORBLIND EQUALITY AND THE \\ PRODUCTION OF RACIAL DifFERENCE}

Even before deciding Fullilove, the Supreme Court had begun to retreat from the presumption of racial proportionality. Beginning in the late $1970 \mathrm{~s}$, that presumption was displaced by a starkly contrasting model of how social and economic goods would be distributed in a

74. H.R. Rep. No. 94-468, at 1-2 (1975).

75. Fullilove v. Klutznick, 448 U.S. 448, 465 (1980) (emphasis added).

76. Id. at 478 .

77. Id.

78. In dissent, Justice Stevens objected explicitly to a "random distribution of benefits on racial lines" serving as a baseline norm that justified a permanent scheme of "special privileges." $I d$. at 539 . 
world without racial discrimination. Under that model, the racial statistics that earlier had proved so compelling were sapped of legal meaning. Courts increasingly interpreted racial underrepresentation as evidence not of discrimination, or as a warrant for a race-conscious remedy, but rather as a manifestation of the underrepresented group's disinclination to obtain its share of the goods in question. In dialogue with influential social scientists and political journalists, the Supreme Court reconstructed African Americans from a class characterized, for the purpose of civil rights enforcement, by the systematic subordination endured by its members, to a class characterized by its ethnic distinctiveness. In so doing, it recast conspicuous racial inequality from an evil in and of itself, to a morally benign legal irrelevancy. This Part examines this conceptual transformation, and argues that it formed an essential theoretical premise for the retrenchment of antidiscrimination law.

\section{A. Racial Inequality in a "Nation of Minorities":} The Ethnicity Critique of Racial Proportionality

The Supreme Court's 1978 opinion in Regents of the University of California v. Bakke $e^{79}$ is a seminal document in the reconstruction of racial inequality as ethnic difference. As the Court's first review of an affirmative action program, Bakke immediately became a legal and rhetorical touchstone in the debate over both race-conscious university admissions and the meaning of racial equality more broadly. The opinion of the Court was authored by Justice Powell, who wrote only for himself. It held that the University of California at Davis Medical School's admissions policy reserving sixteen of its 100 positions for minority applicants was unconstitutional because it denied to nonminority applicants the opportunity to compete for all 100 positions, on account of their race. ${ }^{80}$ Most importantly for the future of affirmative action, five Justices agreed that even "benign" (as opposed to "invidious") racial classifications should be subjected to strict constitutional scrutiny. ${ }^{81}$

79. 438 U.S. 265 (1978).

80. Id. at 319-20.

81. Id. at 299. Justice Stevens' concurring opinion, which was joined by Chief Justice Burger and Justices Rehnquist and Stewart, found it unnecessary to reach the constitutional issue, but joined Justice Powell in striking down the admissions system on the ground that it violated Title IV. Id. at 421 . The principle dissent, authored by Justice Brennan and joined by Justices Marshall, White and Blackmun, contended that benign racial preferences should be subject to intermediate, rather than strict, scrutiny, and concluded that under that standard of review the admissions system should have been upheld. $I d$. at 359. 
Justice Powell's primary analytical challenge was to justify why racial classifications that burdened white males such plaintiff Allan Bakke should be scrutinized as closely as those that burdened "discrete and insular minorities." 82 The discourse of ethnic diversity served as the rhetorical lynchpin of Powell's argument. Since the ratification of the Fourteenth Amendment, he reasoned, the "United States has become a nation of minorities. Each had to struggle-and to some extent struggles still-to overcome the prejudices not of a monolithic majority, but of a 'majority' composed of various minority groups." ${ }^{\prime 3}$ This proliferation of ethnic groups, Powell reasoned, was incompatible with the "artificial line of a two-class theory of the Fourteenth Amendment." 84 The decision adopted in its place a universalist application of the Equal Protection Clause that was more "responsive to the racial, ethnic, and cultural diversity of the Nation." 85

This new democratization of equal protection, however, rendered impossible the task of calibrating judicial scrutiny to the specific status of the racial or ethnic minority burdened by a particular classification. Powell explained:

The concepts of "majority" and "minority" necessarily reflect temporary arrangements and political judgments. ... [T] he white "majority" itself is composed of various minority groups, most of which can lay claim to a history of prior discrimination at the hands of the State and private individuals. ${ }^{86}$

Such an arrangement left courts with "no principled basis for deciding which groups would merit 'heightened judicial solicitude' and which would not."87

For Powell, to vary judicial scrutiny according to the identity of the burdened group was both conceptually incoherent and administratively unmanageable. Cognizable categories of difference had so proliferated since the adoption of the Fourteenth Amendment, he argued, that it was impossible to draw a meaningful distinction between some amorphous racial or ethnic "majority," and "minorities" whose vulnerability at the hands of the majority warranted heightened "solicitude." The proper

82. See United States v. Carolene Products, 304 U.S. 144, 152 n.4 (1938).

83. Bakke, 438 U.S. at 292.

84. Id. at 295 .

85. Id. at 293

86. Id. at 295. As Cheryl Harris writes of Bakke, "social constructionist accounts of race [were] conscripted into the argument that race and racial consciousness cannot be taken into account by the state. .. Through Powell's partial engagement with the idea that the natural is produced by the social, race is deconstructed into a category too incoherent to form the basis of any remedial strategy." Harris, supra note 10, at 1772.

87. Bakke, 438 U.S. at 296. 
solution was to "protect" all groups equally. Powel thus justified the application of strict scrutiny to classifications that burdened white males as the logical extension of a long line of Supreme Court decisions holding that various national and ethnic groups enjoyed heightened constitutional protection. ${ }^{88}$

Under Powell's theory, there existed no legally relevant connection between the present-day disadvantages of particular "ethnic" groups, and those groups' historical experiences of discrimination. Present disadvantage appears, not as an aberration in Bakke, but as a normal stage in a given group's hard-fought ascendancy toward the American socioeconomic mainstream. Accordingly, racial inequality represents less a pernicious vestige of past oppression than an instance of benign ethnic variation that will work itself out over time. Powell's rendering of racial inequality as mere ethnic difference marked a key analytical move in the Court's reconstruction of the Constitution's equal protection mandate, from that of protecting vulnerable minorities to insuring the state's neutrality toward formally equal individuals. ${ }^{89}$

Yet if ethnicity theory provided the rhetorical basis of Powell's case for strict scrutiny, it was also indispensable to his qualified defense of race-conscious admissions. Powell's opinion first validated the diversity rationale for affirmative action. Student body diversity was vital to " $[\mathrm{t}]$ he atmosphere of speculation, experiment and creation[,] so essential to the quality of higher education," he reasoned. Because "the nation's future depends upon leaders trained through wide exposure to the ideas and mores of students as diverse as this Nation of many peoples," 90 Powell concluded, "the attainment of a diverse student body" qualified as a compelling state purpose. ${ }^{91}$

It is important to note what Justice Powell did not say: that student body diversity - the exclusive constitutionally permissible state purpose for race-conscious admissions-had anything to do with remedying past discrimination, or even with racial equality. Rather, a state's interest in "select[ing] those students who will contribute the most to the robust exchange of ideas" 92 resided in a university's "academic freedom," which, "though not a specifically enumerated constitutional right, long has been valued as a special concern of the First Amendment."93

88. See id. at 292.

89. For an informative account of this trajectory, see Jed Rubenfeld, Affirmative Action, 107 YALE L.J. 427 (1997).

90. Bakke, 438 U.S. at 312-13.

91. Id. at 311 .

92. Id. at 313 .

93. Id. at $312-13$. 
Remarkably, the diversity rationale satisfied strict constitutional scrutiny not because it served the values or aspirations embodied in the Equal Protection Clause, but rather in spite of the Court's equal protection review. For constitutional purposes, the "beneficiaries" of raceconscious admissions were not the minority students who, but for their projected contribution to student body diversity, would not have been admitted, but rather the (overwhelmingly white) student body as a whole, particularly the "future leaders" who might otherwise have been deprived of exposure to the nation's "many peoples."

Justice Powell's opinion in Bakke has shaped the American political and constitutional conversation about affirmation for nearly thirty years. One need look no further than the majority opinion in Grutter, ${ }^{94}$ or the enshrinement of the value of "diversity" in corporate America, to appreciate the triumph of the diversity paradigm of racial integration. The enduring force of Justice Powell's opinion resides less in its legal reasoning per se, that in its specific mode of accounting for racial inequality. In particular, it presented inequality in terms that resonated with antiracist understandings of race and racial difference. Justice Powell's insistence on the historical and cultural-as opposed to the natural or genetic-distinctions between social groups shared a great deal with the antiracist rebuke of discrimination advanced by generations of civil rights activists. ${ }^{96}$ Just as importantly, his celebration of ethnic difference meshed rhetorically with the fledgling discourse of multiculturalism. ${ }^{97}$

Justice Powell's carefully calibrated approach to racial inequality was heavily informed by-and, in turn, dramatically amplified the intellectual impact of - a burgeoning body of social scientific literature

94. Grutter v. Bollinger, 539 U.S. 306, 329-30 (ostensibly repudiating the constitutional relevance of either past discrimination or of racial proportionality, while endorsing the importance of achieving student body diversity). See infra discussion at Part III.C.

95. See Erin Kelly \& Frank Dobbin, How Affirmative Action Became Diversity Management: Employer Response to Antidiscrimination Law, 1961-1996, in COLOR LINES, supra note 30, at 87-117 (describing the professionalization of "diversity management" within corporate human resources departments).

96. Michael Omi and Howard Winant explain that the "ethnicity paradigm" approach to race passed through two major stages before it was taken up for the "conservative egalitarian" ends at issue in this Article: "a pre-1930s stage in which the ethnic group view was an insurgent approach, challenging the biologistic (and at least implicitly racist) view of race which was dominant at that time; a 1930 s to 1965 stage during which the paradigm operated as the progressive/liberal 'common sense' approach to race, and during which two recurrent themes-assimilationism and cultural pluralismwere defined." OMI \& WINANT, supra note 5, at 14.

97. See David A. Hollinger, Postethnic America: Beyond Multiculturalism 101 (1995) (discussing the triumph in late-twentieth-century America of the multiculturalist "doctrine" that "the United States ought to sustain rather than diminish a great variety of distinctive cultures carried by ethno-racial groups"). 
on ethnicity. Its most influential author was the Harvard sociologist Nathan Glazer. Powell adapted much of the language of the Bakke opinion, including its rationale for subjecting the Davis program to strict scrutiny, directly from Glazer's account of American ethnic dynamics. "We are indeed a nation of minorities," Glazer wrote in his influential 1975 book, Affirmative Discrimination, and "to enshrine some minorities as deserving of special benefits means not to defend minority rights against a discriminating majority but to favor some of these minorities over others." 98

From the perspective of antidiscrimination law, Glazer's key achievement was simultaneously to acknowledge, and even celebrate, that ethnic difference was a principle feature of American social organization, and yet deny that conspicuous, group-salient inequality carried any moral or legal significance. Although the "ethnic group is one of the building blocks of American society, politics, and economy, none of which can be fully understood without reference to ethnic group formation and maintenance," Glazer wrote, "this type of group is not given any political recognition or formal status." "I9 "If one could draw a neat line between those who have suffered from discrimination and those who have not, the matter would be simpler," Glazer explained. ${ }^{100}$ But most "immigrant groups have had periods in which they were discriminated against. For the Irish and the Jews, for example, these periods lasted a long time."101 The fact that such groups eventually succeeded, Glazer concluded, counseled that the racial and ethnic categories adopted by advocates of affirmative action "neither properly group individuals who deserve redress on the basis of past discriminatory treatment, nor properly group individuals who deserve redress on the basis of a present deprived condition."102

By invoking the example of socioeconomically "assimilated" immigrant groups, Glazer's "nation-of-minorities" model fused rhetorically with the popular narrative of the timeless immigrant struggle to overcome discrimination and ascend the socioeconomic hierarchy. Implicitly, today's disadvantaged minorities would, or at least should, struggle to overcome their legacy of discrimination and disadvantage, just as their discriminated-against and disadvantaged predecessors did. Further, those predecessors, who through hard work and assimilation

98. Nathan Glazer, Affirmative Discrimination: Ethnic Inequality and Public Policy 201 (1975).

99. Id at 28 .

100. Id. at 198 .

101. Id.

102. Id. at 200 . 
had earned their place in the present "majority," could not justly be asked to "bear the burden of redressing a past in which they had no or little part, or assisting those who presently receive more assistance than they did."103 To require them to do so would be to favor one minority over another.

Glazer's formulation denied that past discrimination could adequately account for present racial inequality. And if decoupling present-day inequality from history seems implausible with respect to a groupAfrican Americans-characterized by centuries of unrelenting caste-like subordination, that is where the idea of race-as-ethnicity becomes so rhetorically critical. As Robert Gordon observes, colorblindness proponents assimilated blacks into the immigrant model of ethnic group progress "by imagining 1964 as the date of their 'arrival': once released from legal disabilities, blacks have since been free to compete on equal terms." 104

The rhetorical effect of the blacks-as-American-ethnics story is twofold. First, it suggests that African Americans will follow a path of ethnic progress comparable to that of their immigrant forebears-the Irish, eastern European Jews, Italians, Japanese, and the like. Second, it accounts for racial inequality as an expression of ethnically distinctive culture or taste. Racial inequality is thus tolerable because it is temporary and bound to be diminished with each generation; but even if it persists, it is merely a natural manifestation of black ethnic difference. Under this model, the goals of the civil rights movement have already been satisfied, notwithstanding apparent evidence to the contrary; all that remains for antidiscrimination law is to police against the isolated, exceptional acts of illicit discrimination perpetrated by a handful of racist throw-backs to the Jim Crow era.

For an opinion that formally represented the view of only one Justice, Bakke proved enormously influential, both doctrinally and in its framing of the broader national conversation about the meaning of racial inequality. It bears emphasis that there is nothing inherently invidious about reconceptualizing race in terms of ethnic difference. Indeed, as I suggested above, that impulse shares a great deal with, and draws rhetorical force from, the antiracist discourses of civil rights and multiculturalism. ${ }^{105}$ As it was deployed by colorblindness advocates, however, the reconstruction of racial inequality as ethnic difference was

103. Id. at 201.

104. Robert W. Gordon, Undoing Historical Injustice, in JUSTICE AND INJUSTICE IN LAW AND LEGAL THEORY 52 (Austin Sarat \& Thomas B. Kearns eds., 1996).

105. See supra text accompanying notes $94-97$. 
analytically critical to the mounting critique of affirmative action ${ }^{106}$ and to the ascendancy of the colorblindness model more broadly. Regardless of its historical origins or the political sympathies of its propagators, the idea of black ethnicity has gone a long way toward naturalizing racial inequality.

\section{B. Equality as Colorblind Competition}

By naturalizing conspicuous racial inequality, the ethnicity critique of racial proportionality helped to legitimize the idea that individual competition in a colorblind marketplace produced a just allocation of social and economic goods. In a highly influential article in the Harvard Law Review, which drew liberally from the work of Glazer and other ethnicity theorists, Morris Abram succinctly encapsulated this quintessentially American notion of equality:

The American system guarantees civil and political rights-but it does not guarantee those social and economic rights described in the United Nations' Universal Declaration of Human Rights.... Despite its inevitable inequities, the free market system - also a traditional element of American society-has provided most of our citizens with living standards that are among the highest in the world. As fair shakers [proponents of colorblindness] see it, removing all barriers to the exercise of civil and political rights and an individual's ability to participate in the free market system is the best possible way to promote justice. ${ }^{107}$

106. On the heels of the opinion, the "nation-of-minorities" model became a ubiquitous feature of popular discourse on affirmative action. See, e.g., The Court's Affirmative Action, THE NEW REPUBLIC, Feb. 8, 1978, at 8 (Justice Powell's nation-of-minorities analysis "struck a blow to the practice of "dispensing society's favors" in a way that "encourages this unsavory, competitive aspect of groupthink."); William J. Bennett \& Terry Eastland, Why Bakke Won't End Reverse Discrimination: 1, COMMENT., Sept. 1978, at 31 (Justice Powell's analysis rightly demonstrated that there "is no principled basis . . for deciding which groups would merit heightened judicial solicitude and which would not."). Glazer himself hailed Powell's opinion as "a more sophisticated and complex position on the ethnic character of the United States than I have seen before in any opinion of the Supreme Court." Nathan Glazer, Why Bakke Won't End Reverse Discrimination: 2 CoMMENT. Sept. 1978, at 36, 38. Powell had powerfully "attacked the theory that only stigmatized groups, groups thought inferior, deserve the protection of the Constitution"-a theory that was "remarkably dangerous in a world in which economically and educationally successful minorities have met ... the fiercest discrimination .... "Id. at 38 .

107. Abram, supra. note 19, at 1326. In an insightful critique of the Fifth Circuit's decision in Hopwood v. Texas, 78 F.3d 932 (5th 1996) (striking down as unconstitutional the University of Texas Law School's affirmative action program), Reva Siegel notes the striking parallels between Abram's contention that the American legal system "guarantees civil and political rights" but not "social and economic rights," and the rights regime under Plessy v. Ferguson, 136 U.S. 537 (1896). Siegel, Racial Rhetorics, supra note 10, at 53. During the Reconstruction era, Siegel writes, "overtly hierarchical discourses of racial status were gradually translated into a rhetoric of privacy and associational liberty concerned with projecting racial status relations from governmental interference." Id. at 52. Any race- 
Far from disavowing equality, for Abram and others the colorblind marketplace operationalized the best ideals of the civil rights movement. ${ }^{108}$

Ethnicity discourse, in turn, helped to reconcile the colorblind marketplace with perpetual, conspicuous racial inequality. Glazer, for example, celebrated what he called the "Northern model" of ethnic group relations:

There are many groups. They differ in wealth, power, occupation, values, but in effect an open society prevails for individuals and for groups. Over time a substantial and rough equalization of wealth and power can be hoped for..., and each group participates sufficiently in the goods and values and social life of a common society so that all can accept the common society as good and fair. ${ }^{109}$

Under this model, a particular ethnic group's inferior status reflected not the historical legacy of discrimination, but rather the aggregate achievement of individual group members in the competitive marketplace of education and employment. As the economist Glenn Loury put it, implicit in the system of colorblind opportunity "is a perception of Americans as ... a decent and generous people, believing in fair play and ... ready to welcome individuals of all races and creeds to make of their freedom what they will."110 It was race-conscious public policy, rather than the racially unequal distribution of social and economic goods, that most offended America's fundamental principles of equality. The essential premise of the colorblind marketplace theory of equality was that market-rational decisionmaking and free competition among individuals were logically incommensurate with anything that the law-or common sense, for that matter-should register as discrimination, inequality, or injustice. ${ }^{111}$

salient distributive effects of market competition occupy "a private sphere of racial differentiation that civil rights law may not aspire to disestablish." Id. at 57.

108. Glazer articulated the frequently repeated sentiment that the Civil Rights Act of 1964 "could only be read as instituting into law judge Harlan's famous dissent in Plessy v. Ferguson: 'Our Constitution is color-blind." GLAZER, supra note 98, at 44. In their path-breaking 1975 book on American ethnicity, Glazer and Daniel Moynihan similarly insisted that the "Civil Rights Act of 1964 was the very embodiment of the liberal expectancy.... In particular, government was to be color blind." Nathan Glazer \& Daniel Moynihan, Introduction, in ETHNICITY: THEORY AND EXPERIENCE 10 (Nathan Glazer \& Daniel P. Moynihan eds., 1975).

109. Nathan Glazer, Ethnicity-North, South, West, COMMENT., May 1982, at 73 (quoting Nathan Glazer and DaNiel P. MOYNiHAN, Beyond the Melting Pot (1963)).

110. Glenn C. Loury, Who Speaks for American Blacks?, COMMENT., Jan. 1987, at 34, 35.

111. The Supreme Court likewise invoked colorblind competition as an irreducible touchstone of equality. In Bakke, for example, it was not Davis' racial preference per se that Justice Powell found to have offended the principle of equal protection, but rather the fact that non-minority applicants were "totally foreclosed from competition for the 16 special admissions seats in every [m]edical [s]chool 


\section{Market Outcomes as a Register of Racial Difference}

The colorblind marketplace conception of equality rested on a shallowly submerged and jarringly paradoxical understanding of race. On the one hand, its proponents argued that by disavowing all forms of race-consciousness, colorblindness affirmed the moral irrelevance of race and honored the value of individual achievement within a theater of equal opportunity. When confronted with the fact that the competitive colorblind meritocracy appeared to reproduce existing patterns of racial inequality, however, they embraced accounts of racial difference that in effect rationalized those patterns. The coherence of the colorblindness model thus depended directly, if subtly, on a theory of racial difference. ${ }^{112}$ My claim is not that colorblindness advocates' simultaneous adoption of inconsistent, even contradictory, discourses of race represented a cynical, opportunistic rhetorical strategy. For some, of course, that may well have been the case. I suspect that many, however, were entirely unaware of the tension. Rather, the paradox has been a logical consequence of superimposing the colorblindness model onto a society characterized by severe, entrenched racial inequality.

If the colorblind marketplace functions as its proponents believe-as a competitive meritocracy that justly distributes rewards according to individual desert-it requires only a short logical step to infer that its outcomes accurately register the relative talent, effort, skill, or merit of the individual competitors. In a pure liberal meritocracy, the colorblind marketplace thus operates as a testing ground of individuals, a neutral arbiter of ability and desert, where variations in outcome measure preexisting differences. ${ }^{113}$ Where outcomes form racially or ethnically discernable patterns, those patterns accordingly manifest the real differences between groups. Following this logic, the competitive colorblind meritocracy may well perpetuate racial inequality, but that

class." Regents of Univ. of Cal. v. Bakke, 438 U.S. 265, 305 (1978). "Fairness in individual competition for opportunities, especially those provided by the State," he explained, "is a widely cherished American ethic." Id. at 319 n.53. Indeed, Powell reiterated the point throughout the opinion.

112. See supra note 10 and accompanying text.

113. See, e.g., Kimberlé Williams Crenshaw, Race, Reform, and Retrenchment: Transformation and Legitimation in Antidiscrimination Law, 101 HARV. L. REV. 1331 (1988). In the neoconservative world view of colorblindness proponents, Crenshaw argues, competition for employment, "[u]nimpeded by irrational prejudice against identifiable groups and unfettered by government-imposed preferences, ... would ensure that any group stratification would reflect only the cumulative effects of employers' rational decisions to hire the best workers for the least cost." Id. at 1344-45. Further, "[r]ace consciousness ... reinforces whites' sense that American society is really meritocratic and thus helps prevent them from questioning the basic legitimacy of the free market. Believing both that Blacks are inferior and that the economy impartially rewards the superior over the inferior, whites see that most Blacks are, indeed worse off than whites are, which reinforces their sense that the market is operating "fairly and impartially'; those who should logically be on the bottom are on the bottom." Id. at 1380 . 
fact does not impugn its fundamental justice.

Rather, racial inequality simply manifests ethnic differences. Glazer, for example, has defended group stratification as an affirmation of ethnic traditions. "Racial and ethnic communities have expressed themselves in occupations and work groups," he wrote. ${ }^{114}$

Distinctive histories have channeled ethnic and racial groups into one kind of work or another, and this is the origin of many of the 'unrepresentative' work distributions we see. These distributions have been maintained by an occupational tradition linked to an ethnic community, which makes it easier for the Irish to become policemen, the Italians fruit dealers, Jews businessmen. ${ }^{115}$

And, one might add, blacks janitors, maids, and other low-wage service employees. Glazer's somewhat romantic formulation acknowledges the role of history in "channeling" groups into different strata of the occupational hierarchy but denies that past any moral or legal meaning for the present.

The economist Thomas Sowell inferred a similar lesson from the tendency in "multi-ethnic societies ... for ethnic groups to engage in different occupations, have different levels ... of education, receive different incomes and occupy different place[s] in the social hierarchy."116 Notwithstanding this basic truth, he scolded, advocates of affirmative action regarded this "universality" as an "anomaly." 117 The present disadvantages borne by historically subordinated groups reflected not the legacy of public and private discrimination, Sowell explained, but rather the disposition of those groups to engage in "different" occupations. 118 "One of the more intangible-but very important-differences among groups.... has to do with culture, tradition, values, and work skills."119 Group tastes were embedded in deep, inherited cultural values, he argued.

114. GLAZER, supra note 98, at 203 (emphasis added).

115. GLAZER, supra note 98, at 203 (emphasis added). Constitutional scholar Paul Brest invoked Glazer's ethnic expression argument in his widely influential defense of procedural colorblindness. "Not all racially disproportionate impact[s]," Brest instructed, "can be attributed to past and remote discrimination: culture and social environment play major roles in shaping people's motivations, habits, and skills, and the values voluntarily held by different social groups conduce to differing extents to success on tests and jobs in any society." Paul Brest, Foreward: In Defense of the Antidiscrimination Principle, 90 HARV. L. REV. 1, 32 (1976).

116. Thomas Sowell, “Affirmative Action": A Worldwide Disaster, COMMENT., Dec. 1989, at 21, 23.

117. Id.

118. Id.

119. Id at 23 . 
[A]ttitudes were brought over from Europe .... American society had given the Irish (who arrived earlier) more education that it had to the Jews, but centuries of tradition in Europe had produced very different attitudes toward education in the two groups. "Society" in the United States is not the cause of all American social phenomena. ${ }^{120}$

Accordingly, not every expression of inequality warranted a government remedy.

By denying redress for the effects of past discrimination, antidiscrimination law thus affirmed the integrity of ethnic tradition and group self-determination. Whether racial inequality was rationalized in terms of cultural traditions, the relative adherence to social norms, or outright cultural "pathology,", the effect was to reify an ascribed set of values and attitudes as an essential, constitutive aspect of a group. To the extent that the "cultural" attributes bearing on a group's relative social and economic status were connected to the uniqueness of its history, it was not the history of discrimination against the group that mattered. Nor did the group differences made visible by the process of colorblind competition correspond with the conventional markers of "ethnicity"-for example, distinctiveness in language, religious practice, social and political experience, family structure, or cuisine-that are typically celebrated for their contribution to "diversity." Rather, the differences that mattered were those that set in relief a given group's competitive shortcomings in the colorblind marketplace. ${ }^{122}$ Through

120. Thomas Sowell, Myths about Minorities, CommenT., Aug. 1979, at 33, 36. Glazer and Moynihan put a somewhat more provocative gloss on a similar point. "Men are not equal," they explained; "neither are ethnic groups... [M]en everywhere [are] ranked in systems of social stratification, where one person is better or worse off than another. This is the empirical fact. As with individuals, so with groups of individuals, with social groups defined by ethnic identity." For both ethnic groups and for individuals, inequality "arises from differential success in achieving social norms." GLAZER \& MOYNIHAN, supra note 109, at 108. Nor did those employing the trope of ethnic taste pursue the possibility that some ethnic "traditions" and "preferences" may have been forged in the context of highly circumscribed opportunities. Contrary to the urgings of Glazer and Sowell, it does not follow that antidiscrimination law should presume that such preferences are unproblematically autonomous and deserving of automatic deference. As Cass Sunstein observes, "a social or legal system that has produced preferences, and has done so by limiting opportunities unjustly . . can hardly justify itself by reference to existing preferences." Cass R. Sunstein, The Anticaste Principle, 92 MiCH. L. REV. 2410, 2420 (1994). See also Charles R. Lawrence III, The Id, the Ego, and Equal Protection: Reckoning with Unconscious Racism, 39 STAN. L. REV. 318, 375 (1987) ("Culturalist" accounts of "black inferiority" tend to deny that that race-salient traits are the "result of societal discrimination.").

121. See GLAZER, supra note 98 , at 72 (characterizing blacks' differential adherence to social norms as an inexplicable "tangle of pathology").

122. For some colorblindness advocates, competitive failure in the colorblind marketplace not only evidenced the functional differences between the "cultures" of different ethnic groups, but also inspired explicitly neo-racialist explanations of socioeconomic stratification. Drawing on Arthur Jensen's widely influential 1969 article, "How Much Can We Boost IQ and Scholastic Achievement," Richard Herrnstein, the future co-author (with Charles Murray) of The Bell Curve, alerted would-be advocates of racial proportionality to blacks' low relative performance on IQ tests. R.J. Hermstein, In 
this logic, the colorblind meritocracy functioned as a presumptive register of racial difference. ${ }^{123}$

\section{2. "Social Engineering"}

In keeping with the view that ethnic inequality was natural, inevitable, and benign, colorblindness proponents dubbed those who would disturb the meritocracy of the colorblind marketplace "social engineers." The term appears to have been coined by Morris Abram in his 1986 essay, ${ }^{124}$ but the underlying sentiment has been around as long as affirmative action itself. The word "engineering" conjures up a host of associations: of construction, or fabrication; of manmade-ness; of altering the natural order of things for human purposes. It stands in jarring proximity to the idea of the "social," that distinctly non-governmental realm of human experience, apart from the public arena of politics, law and regulation. "Social engineering" invoked, as Abram no doubt intended, something decidedly unnatural.

According to colorblindness proponents, social engineers threatened to disturb a perfectly normal, morally unproblematic pattern of ethnic variation. In their effort to "bring about proportional representation in short order," 125 Abram explained, the "social engineers thus defy the existing distribution of skills and abilities-whether naturally present or socially developed-in order to achieve their objective."126 In language remarkably reminiscent of the bifurcation of "social" and "political" rights under the Plessy regime, ${ }^{127}$ Abram lamented that a "large segment

Defense of Intelligence Tests, COMMENT. Feb. 1980, at 40. Jensen had demonstrated that "[b]iology seemed more often than not to undermine political and moral ideals. Biology creates inequalities ....." Id. at 41. "Substantial heritabilities are like large unseen rocks in the stream of social life," Hermstein announced, "shaping and at times distorting the effects of institutions and laws defining private relationships ...." $I d$. at 43 . "The time has come to look closely at the facts and to see what they suggest about the possibilities for ethnic faimess in our society," Herrnstein urged. Id. at 49.

123. This logic of racial reproduction bears on what a number of scholars have characterized as the "stigmatic" harm that underrepresentation inflicts on minorities. As Kenneth Karst observed in 1977, "[a] legislature oblivious to ... [the] stigma of [racial] caste will nonetheless reinforce the stigma when it produces racially discriminatory effects through ostensibly 'neutral' legislation." Karst, supra note 4, at 51. Such stigmatic harm flows specifically from the "pattern of denials which resonate or reverberate throughout American society, all tending to declare minorities inferior or limited to a certain place." Jones, supra note 62, at 2355.

124. See Abram, supra note 19 . The phrase itself has enjoyed remarkable success in popular political discourse, finding its way into the lexicons even of some supporters of affirmative action. See, e.g., Michael Kinsley, Class, not Race, THE NEw REPUBlic, Aug. 19, 1991 at 4 ("[A]ffirmative action by social class is still a form of zero-sum social engineering . ...").

125. Abram, supra note 19, at 1313.

126. Id. at 1320 .

127. See Siegel, Racial Rhetorics, supra note 10. 
of the civil rights lobby has turned from the struggle for equality in civil and political rights to the advocacy of redistribution of economic and social rights."128 Political journalist Carl Cohen extended Abram's critique, characterizing the pursuit of racial proportionality as an offense to the quintessential American value of ethnic pluralism:

[The notion of racial "underrepresentation"] relies on the seriously mistaken assumption that, absent discrimination, all ethnic groups would be randomly distributed among all categories of employment.... A just society, on this view, will be a homogenized society ... [ [H]aving confounded equal treatment with proportionality, [s]tatistical "underrepresentation" thus becomes the warrant for racially preferential instruments to set things right.... Human beings commonly work and play, live and study, with fellow members of groups-religious, racial, national-with which they most closely identify themselves. Ethnic clumps [are] the natural product of what we regard with pride as "cultural pluralism."129

Bakke's diversity rationale had come full circle, in an ethnic pluralism defense of racial inequality. To pursue the racial integration of lucrative, high-status social and economic institutions constituted, under this view, an attempt to "homogenize" our celebrated "nation of minorities."

Sowell, in particular, attacked social engineers' practice of inferring the relative magnitude of past discrimination against a given group from that group's present socioeconomic status. Sowell strictly denied that "the economic and other problems of ethnic groups actually vary with the frequency or severity of the sins against them.", "Today's grand fallacy about race and ethnicity," he wrote, "is that the statistical 'representation' of a group - in jobs, schools, etc.- shows and measures discrimination.", 131 Rather, the relative "success" of some ethnic groups in overcoming histories of discrimination conclusively debunked the presumption of racial proportionality. "The history of the Jews, Orientals, and other ethnic groups," he argued, "is relevant and fatally undermines [the] presupposition[]" that past discrimination is the cause of present racial inequality. ${ }^{132}$ "Why one group does better economically than another is a complex question," Sowell

128. Abram, supra note 19, at 1325. Abram liberally cited Sowell and Glazer's ethnicity oriented defenses of racial stratification. See, e.g., id. at 1316 (Sowell has shown that "[g]roups such as the Japanese, Chinese, and West Indian blacks have fared very well in American society despite racial bias against these groups.").

129. Carl Cohen, Naked Racial Preferences, COMMENT., Mar 1986, at 24, 29 (emphasis added).

130. Sowell, supra note 120 , at 34 .

131. Thomas Sowell, Are Quotas Good for Blacks?, CoMMENT., June 1978, at 39, 39.

132. Thomas Sowell, Weber and Bakke, and the Presuppositions of "Affirmative Action," 26 WAYNE L. REV. 1309, 1318 (1980). 
acknowledged, "[b]ut the presence of Jews and Japanese at the top of the income ladder among American ethnic groups is strong evidence that prejudice or discrimination alone is hardly a sufficient explanation." 133

Still more worrisome for Sowell, it was only a "short step" from the eagerness of some Supreme Court Justices to interpret "group disparities in 'representation' . . . as proof of societal discrimination," to "the idea of restoring groups to where they would have been-and what they would have been-but for the offending discrimination." ${ }^{\text {"134 }}$ The presumption that, but for past discrimination, blacks would enjoy economic and educational benefits roughly in proportion to their membership in the population was pure hubris, Sowell believed. Judges might as well ask:

What would the average Englishman be like today "but for" the Norman conquest? What would the average Japanese be like today "but for" the enforced isolation of Japan for two-and-a-half centuries under the Tokugawa shoguns? What would the Middle East be like today "but for" the emergence of Islam? ${ }^{135}$

To presume that, were it not for the legacy of slavery and a century of caste-like discrimination in employment, education, and housing, American blacks would enjoy rough socioeconomic equality with whites, involved an equally improbable act of speculation. As Sowell put it, the "moral uniqueness of black history does not imply a causal uniqueness.", 136

Colorblindness proponents thus condemned government interference with the just rewards of open, meritocratic competition. "If, as seems more likely than not, occupational preferences and abilities are not randomly distributed across all racial and ethnic groups," argued thenProfessor Richard Posner, "then governmental intervention in the labor markets ... will have to continue forever if proportional equality in the desirable occupations is to be secured." 137 Such an "intervention would,

133. Sowell, supra note 120 , at 35. See also, James Nuechterlein, A Farewell to Civil Rights, COMMENT., Aug. 1987, at 25, 35-36 (The history of "Orientals and Jews" in the United States demonstrates that "there is room in the interstices of American society for oppressed minority groups to make a place for themselves and begin the long ascent out of their oppressed status. Blacks, who have suffered quantitatively and qualitatively as no other groups in America has suffered, have nonetheless begun that ascent....").

134. Sowell, supra note 116 , at 26.

135. Sowell, supra note 116 , at 26.

136. Sowell, supra note 132, at 1336. Terry Eastland and William Bennett similarly rejected the presumption that "in the absence of slavery and discrimination in American history blacks and other minorities would be 'naturally' represented today in the various walks of life in something like the statistical patterns they now recommend." TERRY EASTLAND \& WILLIAM J. BENNETT, COUNTING BY RACE: EQUALITY FROM THE FOUNDING FATHERS TO BAKKE AND WEBER 144 (1979).

137. Richard A. Posner, The DeFunis Case and the Constitutionality of Preferential Treatment of 
by profoundly distorting the allocation of labor and by driving a wedge between individual merit and economic and professional success, greatly undermine the system of incentives on which a free society depends." Against a background presumption that colorblind competition accurately registers individual merit, the government's pursuit of greater racial representation, rather than the reproduction of inequality under a colorblindness regime, disfigures the natural distributive order.

To critics of racial proportionality, "social engineers" offended the true values of the civil rights movement and obstructed racial progress both by disregarding real racial differences and, paradoxically, by seeking to make race more, rather than less, relevant in American life. The moment the 1964 Act inscribed the colorblindness principle into law, Glazer complained, "[l]arger and larger areas of employment came under increasingly stringent controls so that each offer of a job, each promotion, each dismissal had to be considered in light of its effects on group ratios . . ." "139 When opponents of race-conscious public policy defended America's presumed colorblind meritocracy against preference-happy racial balancers, by contrast, they claimed to wear the authentic mantle of the Act. Only by scrupulously denying the moral and legal relevance of race, and insisting on a rigorously enforced colorblind meritocracy, could the shared goal of burying the nation's past sins be fulfilled. ${ }^{140}$

The social engineering argument, and the colorblindness critique of racial proportionality more generally, was embedded in a teleology of liberal progress that enabled the (declaredly) anti-racist civil egalitarians who populate the nation's political and judicial bodies to imagine that Brown and the passage of the 1964 Act marked a decisive triumph over the shameful, state-sanctioned racial status hierarchy of the past. The essence of this narrative, Robert Gordon explains, is that "slavery and Jim Crow were great historical injustices because they violated the historically established American basic norm of formally equal treatment of persons, or color blindness."141 Beginning with Brown and

Racial Minorities, 1974 SUP. CT. REV. 1, 18.

138. Id.

139. GLAZER, supra note 98 , at 31 .

140. Colorblindness advocates frequently argued that affirmative action disserved racial equality by stigmatizing the very people it was supposed to benefit. "A quota is a divider of society," Abram insisted, "a creator of castes, and it is all the worse for its racial base, especially in a society desperately striving for an equality that will make race irrelevant." Abram, supra note 19, at 1322 (quoting BICKEL, THE MORALITY OF CONSENT 133 (1975)). By openly snubbing the principle of colorblindness, he continued, "social engineers invite us to view people as statistics; they submerge personality, effort, and character under the blanket concerns of race, sex, and ethnicity." Id.

141. Gordon, supra note 104, at 51. 
culminating in with the 1964 Act, the nation entered "an irenic period of steady progress in race relations, in which one legal barrier after another fell to full legal citizenship and in which the irrationality of racism evaporated in the sunlight of modernity."142 The stakes of this narrative extend well beyond the constitutionality of race-conscious remedies. "Race in this country," writes Morton Horwitz, "has always stood as a constant reminder that each individual is not judged solely as an individual."143 Americans are thus attracted to the colorblindness critique of racial proportionality "primarily in order to avoid having the issue of racial equality overflow its bounds and become involved with the cognate question of the legitimacy of social and economic equality." 144

The colorblindness critique of racial proportionality thus achieved a moral, political, and legal authority far greater than the sum of its component arguments. Its considerable appeal lay as much in what it encouraged its audience to believe about the quality of the American nation, as what it said specifically about race-conscious public policy. In short, the colorblindness model has enabled Americans to reconcile conspicuous, persistent racial inequality with an image of the United States as a fundamentally fair and just place, where people deserve what they get and get what they deserve.

\section{Colorblind COMPETITION, Racial DifFERENCE, AND THE RETRENCHMENT OF ANTIDISCRIMINATION LAW}

The colorblind marketplace vision of racial equality, reinforced by the adjunct discourses of ethnic difference and social engineering, was assimilated directly into the antidiscrimination reasoning of the Supreme Court. By the end of the 1980s, a majority of Justices had expressly disavowed the presumption of racial proportionality, as the Court remade both Title VII and equal protection jurisprudence in the image of the race-neutral competitive marketplace.

\section{A. Title VII: Disparate Impact and the Emergence of the Market Rationality Standard}

Recall from Part I that when the Supreme Court first recognized the disparate impact action in Griggs, it dethroned the intent requirement as an essential component of unlawful discrimination. As I argued, the

142. Id. at 53 .

143. Horwitz, supra note 8 , at 609 .

144. Id. 
underlying premise of disparate impact, and particularly of the Court's strict rendering of the "business necessity" standard, was that in the absence of past or present discrimination, truly meritorious employment practices would usually result in roughly proportionate representation. ${ }^{145}$ Title VII did not necessarily prohibit racially disproportionate results, but it subjected them to considerable scrutiny. Over the course of the 1980 s, as the Court's construction of Title VII increasingly reflected both the ethnicity critique of racial proportionality and the logic of the race-neutral marketplace more broadly, its earlier suspicion of racial underrepresentation evaporated. As a direct result, the Court supplanted the strict necessity rule with a far more deferential standard.

The Supreme Court's 1988 decision in Watson v. Fort Worth Bank and Trust ${ }^{146}$ signaled an emerging consensus among the Justices that the presumption of racial proportionality had no place in Title VII enforcement. On its face, Watson was a case about the technical requirements of the disparate impact action-the parties' respective evidentiary burdens; the degree of specificity with which plaintiffs were required to identify a challenged employment practice; and the applicability of disparate impact analysis to "non-objective" jobselection criteria. Not incidentally, the decision also held in favor of the plaintiffs, and in a very narrow sense even expanded the application of disparate impact reasoning to "subjective" or "informal" employment practices, such as hiring or promotion decisions based on a candidate's job interview or personal rapport with an employer. ${ }^{147}$

Far more consequentially, however, Justice O'Connor's plurality opinion reduced dramatically the burden of defending against a disparate impact claim. First, the opinion held that simply demonstrating that an employer's hiring or promotions system produced a disparate racial impact was insufficient to establish a prima facie case of discrimination. Plaintiffs would now additionally be "responsible for isolating and identifying the specific employment practices that are allegedly responsible for the observed statistical disparities." 148 Next, the opinion shifted the evidentiary burden in the business necessity phase from the defendant to the plaintiff. Chief Justice Burger's holding in Griggs that a challenged practice must have a "manifest relationship to the employment in question"149 for a defendant to escape liability, O'Connor wrote, had been wrongly interpreted to mean that once a

145. See supra text accompanying notes $57-70$.

146. 487 U.S. 977 (1988).

147. Id. at $989-91$.

148. Id. at 994.

149. Griggs v. Duke Power Co., 401 U.S. 424, 432 (1971). 
plaintiff made a prima facie showing of disparate racial impact "the ultimate burden of proof can be shifted to the defendant."150 In a remarkable construal of Supreme Court precedent, she announced that "the ultimate burden of proving that discrimination against a protected group has been caused by a specific employment practice remains with the plaintiff at all times." $" 151$ Finally, and perhaps most importantly, the plurality revised the business necessity standard to a degree that left it nearly unrecognizable. Employers would no longer be required to prove that a challenged practice was "necessary to safe and efficient job performance to survive a Title VII challenge." 152 Drawing on the equal protection holding in Davis, Justice O'Connor announced that in order to show that a challenged practice was justified by business necessity, a defendant needed only to produce "evidence that its employment practices are based on legitimate business reasons ...." "153 As long a defendant could make a plausible showing that the disputed practice served some legitimate business goal, the burden fell to the plaintiff to disprove the defendant's assertion-a weighty task, to say the least.

Notwithstanding Watson's extensive, if analytically questionable, parsing of precedent, as well as its highly technical tone, the plurality opinion ultimately draws its rhetorical force less from Title VII's text or from caselaw than from the distinctly extra-legal discourses of ethnic difference and the race-neutral marketplace. The opinion expressly disavowed the presumption of racial proportionality underlying the earlier disparate impact cases. Justice O'Connor explained that it was "completely unrealistic to assume that unlawful discrimination is the sole cause of the people failing to gravitate to jobs and employers in accord with the laws of chance." 154 There were, she conjectured, "myriad of innocent causes that may lead to statistical imbalances in the composition of their work forces." "155 Although O'Connor would wait until the following Term, in City of Richmond v. Croson, to flesh out this reasoning, her formulation in Watson began to build into Title VII enforcement a key premise of the colorblindness critique of racial proportionality - that race-salient group differences, and not discrimination, were the most likely cause of the documented racial disparities.

150. Watson v. Fort Worth Bank \& Trust, 487 U.S. 977, 997 (1988).

151. Id.

152. Dothard v. Rawlinson, 433 U.S. 321 at 331 , n.14 (1977).

153. Watson, 487 U.S. at 998 (emphasis added).

154. Id. at 992 (emphasis added).

155. Id. 
The opinion simply presumes substantial racial variations in employment tastes and interests. The suggestion that racial groups gravitate differently imputes to the inequality an aura of ineluctability, or naturalness; yet it simultaneously suggests that the challenged disparity is a result of the collective choices of minority individuals. In either case, it resists any suggestion that the disparate impact at issue was attributable either to the effects of past discrimination or to ongoing structural barriers of the sort that concerned the Griggs Court. Somewhat paradoxically, the opinion invokes racial differences in the service of a doctrinal innovation - freeing the defendant of the burden of proving business necessity-designed to minimize employers' legal obligation to notice race.

As in the parallel constitutional controversy around affirmative action, the imputation of social engineering and the specter of racial "quotas" haunted the conflict over the business necessity defense. If defendants' evidentiary burden was set too high, and employers were obliged to satisfy a strict necessity standard, the plurality worried, "quotas and preferential treatment [would] become the only costeffective means of avoiding expensive litigation and potentially catastrophic liability." "into the context of subjective selection practices," in particular, risked encouraging employers to adopt such "inappropriate prophylactic measures," 157 and thus to defy the pre-existing, racially differential distribution of employment tastes and interests. Watson advanced a moral argument against social engineering that intertwined the denunciation of racial quotas with culturally ascendant ideas about ethnic group difference. It was imperative for the Court to fashion evidentiary standards that operated as "adequate safeguards" against this looming hazard. ${ }^{158}$ Accordingly, the Court eliminated liability where the challenged practice satisfied a merely legitimate business purpose. The new standard dramatically constricted the category of racially disparate impacts for which Title VII offered the possibility of redress.

The Watson plurality's discouragement of racial quotas was inseparable from its determination to preserve employers' traditional managerial prerogatives. Disparate impact theory had held such farreaching implications because it construed Title VII to prohibit some employment practices in spite of their instrumental rationality. ${ }^{159}$ This is

156. Id. at 993 .

157. Id. at 992 .

158. Id. at 993 .

159. Christine Jolls explains that in this respect disparate impact liability sometimes operates as an accommodation requirement: "Employers are often required by disparate impact law to incur special 
precisely what concerned the plurality, which worried repeatedly that the imposition of a strict necessity standard might have a "chilling effect on legitimate business practices."160 Whenever possible courts should defer to employers' right to engage in what they believed were rational business practices, ${ }^{161}$ Justice O'Connor reasoned. Requiring disparate impact plaintiffs to carry a heavy evidentiary burden would thus help to ensure that Title VII did not give would-be defendants "incentives to modify any normal and legitimate practices by introducing quotas or preferential treatment."162 When called on to evaluate whether a "discretionary employment practice[] [is] insufficiently related to legitimate business purposes," 163 courts should therefore conduct something akin to a rational basis review in an equal protection challenge. Business rationality was incommensurate with anything that either the law or common sense could properly understand as "discrimination."

Watson's strong deference to practices that merely serve an employer's "legitimate business goals" begs the question of what sorts of practices might expose an employer to disparate impact liability. What would constitute an illegitimate business goal? Presumably, such a practice would be one calculated to disqualify minority candidates at a disproportionately high rate instead of, or at least in addition to, achieving the employer's legitimate business aims. By crediting what amounts to a "market-made-me-do-it" defense, Watson's new, substantially more deferential business necessity standard thus looked much like a test for discriminatory intent. Justice Blackmun stated as much in his concurring opinion, observing that the rule announced by the plurality "bears a closer resemblance to the allocation of burdens we established for disparate-treatment claims ...."164 The procedural and

costs in response to the distinctive needs or circumstances... of particular groups, and these requirements may arise in situations in which the employer had no intention of treating the group differently on the basis of group membership." Christine Jolls, Antidiscrimination and Accommodation, 115 HARV. L. REV. 642, 652 (2001).

160. Watson, 487 U.S. at 993.

161. Marvin Jones observes that in their application of antidiscrimination law to the workplace, courts have operated on the premise that "the employer's 'traditional prerogatives' survive Title VIIthat, in effect, the statute's parameters are framed by common law baselines. The employer's liberty to be free in his domain of any constraints anchors a notion that in the employer's domain he should be free of the government's intruding gaze." Jones, supra note 62, at 2354.

162. Watson, 487 U.S. at 999 . Such deference, moreover, was consistent with the virtue of judicial restraint. Courts should bear in mind that they "are generally less competent than employers to restructure business practices, and unless mandated to do so by Congress they should not attempt it." Id. (citing Furnco Constr. Corp. v. Waters, 438 U.S. 567, 578 (1978)).

163. $I d$.

164. Id. at 1001 (Blackmun, J., concurring in part and concurring in the judgment). 
evidentiary innovations embraced by the Watson plurality were adopted by a five-Justice majority the following term, in Wards Cove Packing $v$. Atonio. ${ }^{165}$

The Civil Rights Act of 1991, amending the 1964 Act to provide the first explicit statutory sanction of disparate impact liability, effectively overturned the most radical aspects of Watson and Wards Cove. The Act's rendering of the business necessity defense was the subject of a protracted and highly politicized negotiation between the first Bush administration and congressional Democrats. The two sides ultimately "resolved" the issue by leaving the terms of the revamped standard deliberately ambiguous. ${ }^{166}$ Most courts and legal scholars agreed,

165. 490 U.S. 642 (1989). Justice White's majority opinion echoed Watson's preoccupation with discouraging quotas; its refusal to presume racial proportionality absent discrimination; its deference to employers' managerial prerogatives; and its equation of instrumental rationality with nondiscrimination. Perhaps most importantly, however, Wards Cove crystallized the market rationality standard, holding that the dispositive issue in a business necessity inquiry was "whether a challenged practice serves, in a significant way, the legitimate employment goals of the employer." $I d$. at 659 . "The touchstone of this inquiry," Justice White explained, was "a reasoned review of the employer's justification for his use of the challenged practice.... [T] here is no requirement that the challenged practice be 'essential' or 'indispensable' to the employer's business for it to pass muster." Id. This formulation decisively rejected the relatively strict necessity standard of Griggs, Albermarle, and Dothard, in favor of something closer to a test for mere business rationality.

In so doing, Wards Cove amplified an impulse that remained relatively latent in Watson: the encroachment of a discriminatory intent requirement into disparate impact analysis. The underlying purpose of the business necessity inquiry had changed. Its basic function was no longer to induce employers to scrutinize the true value of certain presumably well-intentioned practices, but rather to smoke out pretextual invidious discrimination. "A mere insubstantial justification" for a challenged practice was insufficient, the Court acknowledged, "because such a low standard of review would permit discrimination to be practiced through the use of spurious, seemingly neutral employment practices." Id. In theory, of course, "spurious" and "seemingly neutral" practices were the subject of disparatetreatment analysis. This new distribution of evidentiary burdens, explained Justice White, "conforms to the rule in disparate-treatment cases that the plaintiff bears the burden of disproving an employer's assertion that the adverse employment action or practice was based solely on a legitimate neutral consideration." $1 d$. at 660 . One might query, would it mean for the plaintiff to prove that an employment practice was based on an illegitimate or non-neutral consideration, if not that the challenged facially neutral practice was, in fact, a pretext for intentional discrimination? By saddling plaintiffs with the burden of disproving a defendant's assertion that a challenged practice served a legitimate business purpose, the majority appeared to redefine the core evil that disparate impact analysis was designed to redress-from practices which, though neutral on their face and in intent, resulted in a racially disproportionate impact, to practices designed as facially neutral subterfuges for intentional discrimination.

166. The Supreme Court's decision in Wards Cove set off a vigorous two-year political debate over disparate impact liability, and particularly over the proper definition of "business necessity." Congressional Democrats proposed a civil rights bill that essentially overturned Wards Cove, and defined business necessity as "essential to effective job performance." Peter M. Leibold, et al., Civil Rights Act of 1991: Race to the finish-Civil Rights, Quotas, and Disparate Impact in 1991, 45 RUTGers L. REV. 1043, 1072 (1993). Congress passed the Democratic bill in 1990, but President Bush vetoed it, dubbing it a "quota bill" on the theory that a strict necessity standard would compel employers to hire by race (and gender) to avoid liability. Id. at 1071-72 n.113. The President backed a Senate Republican bill that essentially would have codified the market rationality standard of Watson and 
however, that the compromise rule codified by Congress was closer to the strict necessity standard of Griggs and Dothard than the test for mere instrumental rationality set forth in Watson and Wards Cove. ${ }^{167}$

Wards Cove. Under that bill, a challenged practice was "justified by business necessity" so long as it had "a manifest relationship to the employment in question or that the respondent's legitimate employment goals are significantly served by, even if they do not require, the challenged practice." Id. at 1072 .

The following year, moderate Senate Republicans brokered a compromise that deliberately left ambiguous the precise meaning of business necessity. Under Section 105(a) of the 1991 Act, once a plaintiff had made out a prima facie case of disparate impact, a defendant could escape liability by "demonstrat[ing] that the challenged practice is job-related for the position in question and consistent with business necessity." Pub. L. No. 102-166, § 105(a), 105 Stat. 1071, 1074 (codified in scattered sections of 42 U.S.C.). The interpretive memorandum accompanying the Act did little to clarify matters, explaining that the terms "job-related" and "business necessity" were "intended to reflect the concepts enunciated by the Supreme Court in Griggs ... and in other Supreme Court decisions prior to Wards Cove." Spiropoulos, supra note 63, at 1512 (quoting 137 CONG. REC. S15,276 (daily ed. Oct. $25,1991)$ ). Under this formulation, Bush administration officials could, and did, claim that the Act had simply codified Wards Cove, on the theory that the standard set forth in that case reflected an accurate synthesis of Supreme Court precedent up to that time. Senate Democrats and moderate Republicans, by contrast, maintained that Section 105(a) implemented a strict necessity standard, citing the Act's rejection of Wards Cove by name. $1 d$. at 1514 .

167. See Grover, supra note 62; Leibold, et al., supra note 166; Merrick Rossein, Disparate Impact Theory After the Civil Rights Act of 1991: Restoring the Job Performance Standard, 429 Practising LaW InStitute Litigation and Administrative Course Handbook Series 155 (1992). The Supreme Court has not yet directly addressed the meaning of business necessity under the 1991 Act. Notwithstanding Congress' express rejection of the Wards Cove standard, however, the Court's general hostility to racial proportionality reasoning has continued to shape disparate impact doctrine. In particular, over the past several years, the Court has sharply circumscribed Congress' authority under Section 5 to prohibit forms of discrimination that have not been declared unconstitutional by the Judicial Branch. See, e.g., City of Boerne v. Flores, 521 U.S. 507, 519 (1997) (holding that Congress lacked authority under Section 5 to enacted the Religious Freedom Restoration Act, and drawing a sharp distinction between the power to "enforce" the Constitution and the power to define unconstitutional conduct); Kimel v. Florida Bd of Regents, 528 U.S. 62 (2000) (holding that Congress lacked Section 5 authority to abrogate the states' Eleventh Amendment immunity to actions brought under the Age Discrimination in Employment Act of 1967); United States v. Morrison, 529 U.S. 598 (2000) (holding that Congress lacked Section 5 authority to create, in the Violence Against Women Act, a federal civil action for gender-based violence). But see Nevada Dep't of Human Res. v. Hibbs, 538 U.S. 721, 728 (2003) (upholding Congress's Section 5 authority to enact provisions of the Family and Medical Leave Act proscribing "facially constitutional conduct, in order to prevent and deter unconstitutional conduct"). Although Title VII does not traffic in express racial classifications, the fact that disparate impact enforcement sometimes is animated by a racially allocative motive could theoretically trigger the same exacting standard of constitutional review that applies to other racially motivated state action, such as affirmative action.

Operating in the shadow of this prospect, lower courts posed with the question of whether disparate impact liability is an improper exercise of Congress's Section 5 power have begun to minimize the very features of disparate impact that make it a uniquely ambitious form of antidiscrimination law: the fact that the absence of discriminatory intent does not absolve defendants of liability for employment practices which, though instrumentally rational, disproportionately burden members of a protected class. The Eleventh Circuit concluded, for example, that in order for the court to uphold the Civil Rights Act's disparate impact provisions as valid Section 5 enforcement legislation, it would have to find that "the core congressional motivation" behind disparate impact was "consistent with the notion that what the Constitution prohibits is intentional discrimination on the part of state actors (and not state action that 


\section{B. Ethnic Difference and Equal Protection: Public Contracting}

As in the case of disparate impact liability, the Supreme Court drew directly on the coordinate discourses of black ethnicity and social engineering to purge the presumption of racial proportionality from equal protection review. In doing so, it remade constitutional review of affirmative action in the image of the colorblind marketplace. Recall that in the 1980 Fullilove case, the Supreme Court's willingness simply to infer that present racial disparities in the construction industry reflected the direct, continuing effects of past discrimination ratified Congress's adoption of a federal minority set aside program as Fourteenth Amendment enforcement legislation. As I argued above, that inference rested squarely on the Court's strong background presumption of racial proportionality. By the end of the decade, however, that presumption had given way to a discourse of racial inequality centering instead on ethnic group preferences, as the Court adopted a very different theory of how economic opportunities would likely be distributed in a world without discrimination.

Perhaps more than any other decision, the 1989 case of Croson v. City of Richmond starkly illustrates the doctrinal impact of the colorblindness/black ethnicity/social engineering critique of racial proportionality on the Supreme Court's equal protection jurisprudence. Under review in Croson was the Richmond Plan, a city ordinance requiring prime construction contractors receiving city contracts to subcontract at least thirty percent of the contract value to minority business enterprises. ${ }^{168}$ In contrast to Chief Justice Burger's majority decision in Fullilove, both Justice O'Connor's plurality opinion and Justice Scalia's concurrence subjected the Richmond Plan to strict

leads merely to discriminatory results.)" In re: Employment Discrimination against the State of Alabama, 198 F.3d 1305 (11th Cir. 1999). "Though the plaintiff is never explicitly required to demonstrate discriminatory motive," the court reasoned, "a genuine finding of disparate impact can be highly probative of the employer's motive since a racial imbalance is often a tell tale sign of purposeful discrimination." Id. at 1321 (quoting Int'l Bhd. of Teamsters v. U.S., 431 U.S. 324, 339-40 n.20 (1977)). In fact, "although the form of the disparate impact inquiry differs from that used in a case challenging state action directly under the Fourteenth Amendment, the core injury targeted by both methods of analysis remains the same: intentional discrimination." Id. at 1322 . With this rendering of disparate impact, State of Alabama essentially revived the "sociological radar" approach of the preGriggs era. Perhaps most importantly, it virtually obviated Title VII's long-standing scrutiny of employment practices that are instrumentally rational and free from discriminatory purpose, but which disproportionately burden a protected class. See generally Jolls, supra note 159; Robert C. Post \& Reva B. Siegel, Equal Protection by Law: Federal Antidiscrimination Legislation After Morrison and Kimel, 110 YALE L.J. 441 (2000); Richard A. Primus, Equal Protection and Disparate Impact: Round Three, 117 HARV. L. REV. 493 (2003).

168. 488 U.S. 469,477 (1989). 
constitutional scrutiny. ${ }^{169}$ Because the ordinance employed express racial classifications, it would only be upheld if it was narrowly tailored to serve a compelling state purpose.

In Fullilove, the Court had virtually taken for granted the remedial purpose of the challenged statute. For the Court to find that the "remedy" at issue in Croson served a compelling state purpose, however, the Richmond City Council would have to identify the alleged discrimination "with the particularity required by the Fourteenth Amendment." "When the City Council enacted the ordinance, it had relied on a study showing that "while the general population of Richmond was $50 \%$ black, only $0.7 \%$ of the city's prime construction contracts had been awarded to minority businesses" over a recent fiveyear period. ${ }^{171}$ Notwithstanding this seventy-five-fold disparity between the percentage of blacks living in Richmond and the percentage of prime contracts awarded to minority contractors, the plurality flatly refused to infer that minority "underrepresentation" had anything to do with past discrimination in the construction industry. "It is sheer speculation," Justice O-Connor wrote, "how many minority firms there would be in Richmond absent past societal discrimination, just as it was sheer speculation how many minority medical students would have been admitted to the medical school at Davis absent past discrimination...." 172 Far from reflecting the effects of discrimination, there were "numerous explanations for this dearth of minority participation, including past societal discrimination in education and economic opportunities as well as both black and white career and entrepreneurial choices. Blacks may be disproportionately attracted to industries other than construction." 173 This refusal to credit the documented racial disparity as evidence of discriminationparticularly the suggestion that blacks, as a group, could be seventy-five times less "attracted" to construction than whites-reflects a truly dramatic rejection of the presumption of racial proportionality operating in Fullilove, as well as Title VII cases such as Griggs.

The plurality's application of the narrow tailoring requirement was equally implausible. Given the magnitude of the disparity at issue,

169. The plurality distinguished the case from Fullilove on the basis of Congress' superior authority to enforce the Fourteenth Amendment with appropriate legislation. "That Congress may identify and redress the effects of society-wide discrimination," Justice O'Connor wrote, "does not mean that, a fortiori, the States and their political subdivisions are free to decide that such remedies are appropriate." Id. at 490.

170. Id. at 492 .

171. Id. at $479-80$.

172. Id. at 499.

173. Id. at 503 . 
Justice O'Connor's treatment of Richmond's " $30 \%$ quota" borders on hyperbole. She insisted that the program rested on "the completely unrealistic assumption that minorities will choose a particular trade in lockstep proportion to their representation in the local population.... [I]t is completely unrealistic to assume that individuals of one race will gravitate with mathematical exactitude to each employer... absent unlawful discrimination." "74 The plurality's assertion that the ordinance demanded "lockstep proportion" and "mathematical exactitude" appears almost cynical. As Justice Marshall noted in dissent, "[w]hile the measure affects $30 \%$ of public contracting dollars, that translates to only $3 \%$ of overall Richmond area contracting."

Further, the plurality's rejection of Richmond's asserted purpose of remedying societal discrimination sounds explicitly in Bakke's "nation of minorities" argument. To accept the city's position that a mere finding of past societal discrimination warranted a system of "rigid racial preferences would... open the door to competing claims of 'remedial relief' for every disadvantaged group. The dream of a Nation of equal citizens in a society where race is irrelevant to personal opportunity and achievement would be lost in a mosaic of shifting preferences based on inherently unmeasurable claims of past wrongs." To countenance such a principle, moreover, would require courts to perform the impossible task of evaluating "the extent of the prejudice and consequent harm suffered by various minority groups." 177

Croson illustrates the Court's almost seamless appropriation of the discourse of ethnic difference into its constitutional critique of racial proportionality. By advancing a narrative of minority "underrepresentation" that accounted for racial disparities not by reference to past discrimination, but rather through speculation about blacks' racially distinctive entrepreneurial interests and choices, the plurality disavowed the presumption of racial proportionality that underlay the Court's decision in Fullilove. Further, by declining to infer discrimination from even gross racial inequality, Croson saddled state and local governments seeking to redress inequality through raceconscious means with a substantially heavier evidentiary burden.

Six years later, in Adarand Construction v. Peña, ${ }^{178}$ the Supreme Court extended the holding in Croson to federal set-asides as well,

174. Id. at 507-08 (emphasis added) (quoting Local 28 of Sheet Metal Workers v. EEOC, 478 U.S. 421, 494 (1986) (O'Connor, J., concurring in part and dissenting in part)).

175. Id. at 548-48 (Marshall, J., dissenting).

176. Id. at $505-06$.

177. Id. at 506 (quoting Regents of Univ. of Cal. v. Bakke, 438 U.S. 265, 296-97 (1978)).

178. 515 U.S. 200,229 (1995). 
establishing that even congressional efforts to remedy past discrimination by the federal government would be subject to strict scrutiny. ${ }^{179}$ Justice O'Connor's plurality opinion in Croson, as well as Justice Powell's opinion in Bakke, provided the analytical blueprint. In justifying the application of strict scrutiny to even "benign" discrimination, Justice O'Connor's majority opinion explicitly adopted Justice Powell's nation-of-minorities argument. Quoting directly from Bakke, the majority affirmed that because the "guarantee of equal protection cannot mean one thing when applied to one individual and something else when applied to persons of another color," "[r]acial and ethnic distinctions of any sort are inherently suspect and thus call for the most exacting judicial examination." 180

\section{The Ambiguous Legacy of Racial Proportionality: Affirmative Action in Higher Education}

As we have seen, during the 1980 s the ethnicity critique of racial proportionality captured the imagination of various Supreme Court Justices, and in turn directly shaped the development of federal antidiscrimination jurisprudence. In Watson and Wards Cove, the Court retreated from Griggs, and in so doing rejected the key distinguishing elements of disparate impact liability. In Croson, the discourse of black ethnicity rationalized the Court's application of strict scrutiny to, and ultimate rejection of, racial preferences in competition for public construction contracts. In the context of affirmative action in higher education, however, the fate of racial proportionality as a constitutional value is considerably more ambiguous.

Recall that in Bakke, Justice Powell held that even "benign" uses of race in university admissions were subject to strict constitutional scrutiny. ${ }^{181}$ Under that standard, neither compensating a particular group for past discrimination, nor attempting to restore that group to the position it might have occupied but for the alleged discrimination, qualified as a compelling state purpose. Recall also, however, that ethnicity theory simultaneously supplied the sole constitutionally valid purpose for race-conscious admissions-namely, the attainment of student body diversity. As I argued above, the diversity rationale disavowed any interest in redressing racial inequality. Rather, the nominal "beneficiaries" of affirmative action were not the applicants whose minority status triggered the preference, but the overwhelmingly

179. Id. at 227 .

180. Id. at 218 (quoting Bakke, 438 U.S. at 289-91).

181. See supra text accompanying note 73 . 
white student body, which would benefit educationally from exposure to students ethnically different from themselves. ${ }^{182}$

Although civil rights activists, progressive constitutional scholars, and the four Bakke dissenters harshly criticized the strict scrutiny component of Powell's opinion, many within the civil rights coalition have long since adopted the diversity rationale as their own. For the past quarter century, the opinion has both provided the basic ground rules for university admissions programs, ${ }^{183}$ and framed the public and constitutional debate around affirmative action. And when the Supreme Court revisited the question of race-conscious university admissions in 2003 , the continuing constitutional validity of the diversity rational was squarely at issue. Although the case technically resulted in a split decision for the University of Michigan's affirmative action regime, the outcome has been widely viewed as a victory for affirmative action's defenders because the Court, by a margin of six to three, affirmed Bakke's holding that the attainment of a diversity student body constitutes a compelling state interest. ${ }^{184}$

How does the Court's opinion in Grutter v. Bollinger, the decision upholding Law School's admissions program, comport with its approach to disparate impact liability under Title VII, and with its analysis of racial preferences in public contracting under the Fourteenth Amendment? On the one hand, Grutter appears largely consistent with the Court's broader retreat from racial proportionality reasoning. Justice O'Connor's majority opinion faithfully recapitulates the key elements of the Bakke opinion. In particular, it reaffirms that the Fourteenth Amendment prohibits a public university from employing raceconscious means for the purpose of promoting racial equality, and insists that the university's interest in attaining a diverse student body rests exclusively in its First Amendment right of "educational autonomy." "185

182. See supra text accompanying notes 91-93.

183. As the Court observed in Grutter v. Bollinger, 539 U.S. 306, 323 (2002), "[s]ince this Court's splintered decision in Bakke, Justice Powell's opinion announcing the judgment of the Court has served as the touchstone for constitutional analysis of race-conscious admissions policies. Public and private universities across the Nation have modeled their own admissions programs on Justice Powell's views on permissible race-conscious policies."

184. In Gratz v. Bollinger, 539 U.S. 244 (2003), the Court struck down the University's undergraduate admissions system on the grounds that its practice of assigning a fixed number of bonus points to minority applicants failed the narrow tailoring requirement. In Grutter v. Bollinger, however, the Court upheld the Law School admissions program, finding that its practice of considering an applicant's race as one of many qualitative factors was sufficiently narrowly tailored to survive strict scrutiny. 539 U.S. at 306.

185. Grutter, 539 U.S. at 329. "[G]iven the important purpose of public education and the expansive freedoms of speech and thought associated with the university environment," O'Connor explained, the Court had long recognized that "universities occupy a special niche in our constitutional tradition." Id. 
Indeed, the Law School's policy survived strict scrutiny precisely because it "did not purport to remedy past discrimination," or seek "to assure within its student body some specified percentage of a particular group merely because of its race or ethnic origin."186 Rather, it sought only "to enhance classroom discussion and the educational experience both inside and outside the classroom."187 To attempt more, the majority stresses, "would amount to outright racial balancing, which is patently unconstitutional."188

On the other hand, at several important junctures the majority's discussion of the meaning and value of student body diversity clearly exceeds the scope of permissible state interests prescribed by Justice Powell in Bakke. The remainder of this Section argues that even as Justice O'Connor's majority opinion purports to reject any interest in racial remediation or representation, and to adhere faithfully to the Bakke framework, it in fact substantially expands that framework in order to accommodate a range of ostensibly prohibited interests. In particular, under the rubric of the educational benefits that flow from a diverse student body, Grutter both reintroduces the banished concept of past discrimination, and revives the long-dormant value of racial representation. Let us consider four specific examples.

First, recall that in Bakke the value of diversity consisted of the educational benefits that presumably would flow from the student body's "wide exposure' to the ideas and mores of students as diverse as this Nation." 189 Grutter nominally adopts this formulation but gives it a much richer and more pointed meaning. "Just as growing up in a particular region or having particular professional experiences is likely to affect an individual's views," reasons Justice O'Connor, "so too is one's own unique experience of being a racial minority in a society, like our own, in which race unfortunately still matters." 190 "By virtue of our Nation's struggle with racial inequality," she explains, underrepresented minority students "are both likely to have experiences of particular importance to the Law School's mission, and less likely to be admitted in meaningful numbers on criteria that ignore those experiences." 191 This language marks a subtle but important shift in the diversity rationale. In Bakke, Justice Powell's invocation of "our nation-ofminorities" effectively extruded from contemporary racial inequality any

186. Id. (quoting Bakke, 438 U.S. at 30 (internal citations omitted)).

187. Id. at 319.

188. Id. at 331 .

189. Bakke, 438 U.S. at 313 (quoting Keyishian v. Bd. of Regents, 385 U.S. 589,603 (1967)).

190. Grutter, 539 U.S. at 333.

191. Id. at 338. 
moral or legal import. By contrast, Justice O'Connor's gloss on Powell's opinion reads back into the notion of ethnic difference the joint presumption that minority applicants are likely to have experienced racial discrimination, and that their underrepresentation under a raceblind admissions system is the direct consequence of that experience. Grutter thus reintroduces the concept of racial inequality-not, strictly speaking, as an argument per se for the constitutionality of racial preferences, but rather as a valuable and relevant experiential aspect of our nation's diversity. Although this revamped diversity interest remains doctrinally within the register of "educational benefits," its rhetorical force comes directly from its close association with racial discrimination and inequality.

Second, Grutter transmutes diversity from, as Robert Post has put it, a "value intrinsic to the educational process itself" to an "instrument[] for the achievement of extrinsic social goods." "192 By way of explaining how the value of student body diversity is "not theoretical but real,"193 the majority opinion describes its benefit to institutions well beyond the university itself. Drawing on an amicus brief submitted by several large corporate employers, the Court observes that "major American businesses have made clear that the skills needed in today's increasingly global marketplace can only be developed through exposure to widely diverse people, cultures, ideas, and viewpoints." 194 If the majority had stopped there, we might simply interpret this passage as support for the claim that student body diversity promotes a certain functional utility-a set of valuable job skills-for the university graduates and the companies that employ them. In the very next sentence, however, the opinion quietly advances to a superficially related, though in fact entirely novel, argument:

What is more, high-ranking retired officers and civilian leaders of the United States military assert that, "[b]ased on [their] decades of experience," a "highly qualified, racially diverse officer corps ... is essential to the military's ability to fulfill its principle mission to provide national security." ... At present, "the military cannot achieve an officer corps that is both highly qualified and racially diverse unless the service academies and the ROTC used limited race-conscious recruiting and admissions policies."

Within the space of a single paragraph, Justice O'Connor moves directly

192. Post, supra note 9 , at 60.

193. Grutter, 539 U.S. at 330.

194. Id.

195. Grutter, 539 U.S. at 331 (quoting Brief of Julius W. Becton, Jr. et al,, as Amici Curiae at 27) (first omission in original). 
from the benefits to a class of racially non-specific future employees of exposure to diverse peoples and view points, to the benefits to the United States military of an actually racially diverse officer corps. Although the interest of achieving a racially diverse officer corps-or workforce, for that matter-shares little with Bakke's educationalbenefits framework beyond the superficial rubric of diversity, the passage treats the two as though they are logically congruent. In fact, the interest in promoting a racially diverse officer corps bears a significant resemblance to one of the state purposes that the Powell opinion expressly rejected - that of fostering a corps of minority physicians who would presumably be more inclined to practice in underserved, predominantly minority areas. ${ }^{196}$ At any rate, the pursuit of racial integration in institutions extrinsic to the university itself sounds much more clearly in the register of racial representation than in that of educational benefits. ${ }^{197}$

Third, relying explicitly on Brown and other seminal school desegregation cases, the Grutter majority both links the diversity rationale to the racial integration of higher education, and situates affirmative action within the narrative of the nation's long march toward equal opportunity. Because "education is the very foundation of good citizenship," the majority reasons, "the diffusion of knowledge and opportunity through public institutions of higher education must be accessible to all individuals regardless of race or ethnicity."198 "Access to legal education (and thus the legal profession)," it continues, "must be inclusive of talented and qualified individuals of every race and ethnicity, so that all members of our heterogeneous society may participate in the educational institutions that provide the training and education necessary to succeed in America."199 Borrowing the rhetoric, though not the legal reasoning, of the United States' amicus brief submitted in support of the plaintiff, the majority concludes that "[e]ffective participation by members of all racial and ethnic groups in

196. Regents of Univ. of Cal. v. Bakke, 438 U.S. 265, 310-11 (1978).

197. Indeed, each of the four Grutter dissenters explicitly accused the majority of sanctioning unlawful racial balancing. See Grutter, 539 U.S. at 347 (Scalia, J., dissenting) (asserting that the "critical mass" rationale is "a sham to cover a scheme of racially proportionate admissions"); id. at 379 (Rehnquist, C.J., dissenting) (characterizing the Law School's admissions program as a "naked effort to achieve racial balancing"); $i d$. at 389 (Kennedy, J., dissenting) (characterizing the program as an "effort to achieve racial balance among [ ]minorities"). Justice Thomas, in particular, made extensive rhetorical use of "social engineering" discourse. See id. at 350,361,369, 372 (denouncing university administrators' racial "meddling," "tinkering," and social "experimentation" with "other people's children").

198. Grutter, 539 U.S. at 331 (quoting Brown v. Bd. of Educ., 387 U.S. 483, 493 (1954)) (omissions in original).

199. Id. at 332-33. 
the civic life of our nation is essential if the dream of one Nation, indivisible, is to be realized."200

This argument is notable for two reasons. As the emphasis on "accessibility" and minority "participation" indicate, it is concerned less with the educational benefits of diversity than with racial integration. In addition, it couples the integration of the Law School to the national project of redressing racial inequality and mending the nation's historical racial divide. In both respects, the majority locates the goals of the Law School policy-and affirmative action in university admissions more broadly-squarely within the school desegregation tradition inaugurated by Brown. ${ }^{201}$

Fourth and finally, the majority expresses a keen awareness that conspicuous racial underrepresentation reflects poorly on the underlying justice of the American system. "In order to cultivate a set of leaders with legitimacy in the eyes of the citizenry," it reasons, "it is necessary that the path to leadership be visibly open to qualified individuals of every race and ethnicity."202 "All members of our heterogeneous society must have confidence in the openness and integrity of the educational institutions that provide this training," it continues, and because "universities, and in particular law school, represent the training ground for a large number of our Nation's leaders, ${ }^{203}$ racial inclusiveness takes on heightened importance. This argument, perhaps more than any other, suggests that more is at stake in race-conscious admissions than Justice Powell's nation-of-minorities framework could possibly contemplate. With her talk of "visibility" and public "confidence," Justice O'Connor is clearly concerned with appearances-both of the student body and of the nation's future leadership corps. Most importantly, however, her reference to ensuring "legitimacy in the eyes of the citizenry" raises the specter of a much more profound problem: that minority underrepresentation-at the nation's elite public law schools and in civic life-implicates the fundamental justice of the American structure of opportunity. ${ }^{204}$

200. Id. at 332 .

201. Justice Scalia, in dissent, singled out the majority's "lessons in citizenship" interest for special contempt. Preparation for "good "citizenship" was not, he mocked, "an educational benefit on which students will be graded on their law school transcript (Works and Plays Well with Others: $\mathrm{B}+$ ) or tested by the bar examiners (Q: Describe in 500 words or less your cross-racial understanding)." Grutter, 539 U.S. at 347 (Scalia, J., dissenting).

202. Id. at 332 (emphasis added).

203. Id.

204. Justice Thomas found the majority's reference to public "legitimacy" an especially "disturbing" symptom of impermissible and unwise racial balancing. Grutter, 539 U.S. at 373. "[F]or those who believe that every racial disproportionality in our society is caused by some kind of racial discrimination," he chided, "there can be no distinction between remedying societal discrimination and 
Some or all of these four permutations of the diversity rationale-i) the assimilation of the experience of discrimination into the concept of viewpoint diversity; ii) the conflation of the educational benefits of student body diversity with actually integrated social and political institutions; iii) the attainment of student body diversity as an aspect of racial desegregation and citizenship training; and, iv) the preservation of public confidence in equality of opportunity - may well be compelling arguments in favor of race-conscious university admissions; none, however, falls within the scope of state interests previously sanctioned by the Supreme Court. Rather, the majority's explication, or reinterpretation, of the diversity interest suggests that, in spite of its emphatic disavowal of racial proportionality, several of the Justices remain unwilling, at least in the critical context of university admissions, to fully dissociate equal protection enforcement from the goals of racial remediation, integration, and equality. The discussion above suggests, to the contrary, that the diversity rationale obscures a cluster of other values-antisubordination values-that absolutely inform the Court's judgment about the constitutional permissibility of race-conscious admissions. ${ }^{205}$

Does it matter that antisubordination values inform Grutter's constitutional justification for race-conscious university admissions only surreptitiously and without formal doctrinal recognition, rather than as constitutionally compelling state interests in their own right? After all, as this Section has demonstrated, Justice O'Connor's transmuted diversity rationale successfully accommodates, and even operationalizes, those values. On the other hand, by denying them a formal, secure doctrinal home, it also leaves them vulnerable. By refusing to afford any formal legal status to the prohibited interests in remediation, or integration, or racial representation, and instead relegating them to the constitutional netherworld of the diversity rationale, the Grutter majority suppresses candid doctrinal recognition of the enormous social, political, and moral stakes of affirmative action today. In so doing, it relieves the Court, and the rest of the nation, from having to confront directly the question of why, fifty years after Brown and forty years after the 1964 Act, race-conscious public policy remains necessary to attain

erasing racial disproportionalities in the country's leadership caste. And if the lack of proportional racial representation among our leaders is not caused by societal discrimination, then 'fixing' it is even less of a pressing public necessity." Id. at 373-74.

205. Reva Siegel and Jack Balkin insightfully demonstrate how antisubordination values, though formally disfavored by the Court, have persistently and critically shaped the implementation of the anticlassification rule and played an essential role in determining what antidiscrimination law permits and prohibits in practice. See Balkin \& Siegel, supra note 20, at 13-16. See also Post, supra note 9, at $68 \mathrm{n} .306$ (noting that "[t]he implicit logic of remedy actually pervades much of the rhetoric of Grutter"). 
meaningful racial integration. ${ }^{206}$

\section{CONCLUSION}

Grutter seriously complicated the constitutional status of racial proportionality. In Croson, for example, Justice O'Connor had worried that if the Court were to sanction racial preferences, " $[t]$ he dream of a Nation of equal citizens in a society where race is irrelevant would be lost...."207 In Grutter, by contrast, she declared that the racial preference at issue was not only constitutionally permissible but essential "if the dream of one Nation, indivisible, is to be realized."208 The respective subject matter of the two cases-public construction contracting versus university admissions-may help to explain their different outcomes. Yet this alone cannot account for the Court's virtual inversion of social and constitutional reasoning. Rather, the Court's refusal to fully divorce antidiscrimination law from the value of racial proportionality - which is in may ways Justice O'Connor's refusalreveals the difficulty faced by all but the most unflinching partisans of colorblindness when that model is extended to its logical conclusion.

Nathan Glazer confronted the same difficulty. Long among the nation's most sophisticated and influential critics of affirmative action, in 1998 Glazer came out in defense of racial preferences in university admissions, at least for African Americans. Writing in The New Republic, Glazer explained:

Thirty years ago, with the passage of the great civil rights laws, one could have reasonably expected-as I did-that all would be set right by now. But today, even after taking account of substantial progress and change, it is borne upon us how continuous, rooted, and substantial the differences between African Americans and other Americans remain. ${ }^{209}$

Under such conditions, "an insistence on color-blindness means the effective exclusion today of African Americans from positions of

206. Justice Thomas, though writing from a normative perspective very different than that of this Article, raises a critique of affirmative action and the diversity rationale that is not totally foreign to the one suggested here. "'Diversity,' for all its devotees, is more a fashionable catchphrase that it is a useful term," and "presents only an illusory solution to the challenges facing our Nation." Grutter, 539 U.S. at 355 n.3. As long as "it is sufficient that the class looks right, even if it does not perform right," the racial "aestheticists" who administer the University's admissions system "will never address the real problems facing 'underrepresented minorities."' $I$ d. at 372 (Thomas, J., dissenting).

207. City of Richmond v. J.A. Croson Co., 488 U.S. 469, 505-06 (1989).

208. 539 U.S. at 332.

209. Nathan Glazer, In Defense of Preference, THE NEw REPUBLIC, April 6, 1998 at 18, 24. 
influence, wealth, and power."210 Truly uncompromising opponents of affirmative action not only declare themselves prepared to accept such a result, Glazer explained, but believe that the abolition of preferences "will actually ... improve race relations." "211 "Yet we cannot be quite so cavalier about the impact on public opinion-black and white-of a radical reduction in the number of black students" at the nation's elite universities, he cautioned. After all, such institutions are

the gateways to prominence, privilege, wealth, and power in American society. To admit blacks under affirmative action no doubt undermines the American meritocracy, but to exclude blacks from them by abolishing affirmative action would undermine the legitimacy of American democracy. ${ }^{212}$

And what of the notion of black ethnicity - of the idea that African Americans, like Italian Americans, or Jewish Americans, or Japanese Americans, would, with time and struggle, be assimilated fully into the fabric of American life without the benefit of racial preferences? "[T]he varied ethnic and racial groups in the United States do not, to the same extent as African Americans, pose a test of the fairness of American institutions," Glazer explained. "These other groups have not been subjected to the same degree of persecution or exclusion. There status is not, as the social status of African Americans is, the most enduring reproach to the egalitarian ideals of American society."213

As this Article has demonstrated, to the extent that the colorblindness model has reproduced conspicuous racial disparities, it has also generated neo-racialist accounts of black inequality. Through the discourse of black ethnicity, Justice Powell, Justice O'Connor, Glazer, Sowell, and a legion of other critics of racial proportionality fashioned a distinctly modern, ostensibly anti-racist account of racial difference, which they used to explain why most racial inequality lay beyond the proper scope of antidiscrimination law. The discourse of black ethnicity, I have argued, has enabled colorblindness proponents to mediate the contradiction between the genuinely egalitarian aspirations of the colorblindness ideal and the glaring racial inequalities that persist under that model. Both Justice O'Connor's reasoning in Grutter and Glazer's own intellectual reversal, however, suggest that this ideological edifice is crumbling. The discourse of black ethnicity may have furnished reassurance to conservative egalitarians striving to account for 
the persistence of racial inequality in the wake of the 1964 Act. More than a generation later, however, the immigrant analogy perhaps offers less solace, as enduring, entrenched inequality looks less like a morally benign expression of ethnic difference than a grim referendum on the American structure of opportunity. 
